\title{
Record of Early to Middle Eocene paleoenvironmental changes from lignite mines, western India
}

\author{
Sonal Khanolkar ${ }^{1}$ and Jyoti Sharma ${ }^{2}$ \\ ${ }^{1}$ Department of Earth Sciences, Indian Institute of Technology Kanpur, Kanpur, India \\ ${ }^{2}$ Department of Geology, K. J. Somaiya College of Science and Commerce, \\ University of Mumbai, Mumbai, India \\ Correspondence: Sonal Khanolkar (sonal.k.12@gmail.com)
}

Received: 21 May 2018 - Revised: 21 November 2018 - Accepted: 3 December 2018 - Published: 18 January 2019

\begin{abstract}
Various Eocene hyperthermal events have been recorded from lignite sections of western India in the past decade. To infer the paleoenvironment, during a warm paleotropical climate of India, we have assessed multiple microfossil groups like pollen/spores, dinoflagellates and foraminifera from Early Eocene lignite mine sections from the Cambay (Surkha) and Barmer (Giral) basins and Middle Eocene sections from the Kutch Basin (Matanomadh and Panandhro mines) of western India. The Surkha and Giral sections exhibit a dominance of rainforest elements (Arengapollenites achinatus, Longapertites retipilatus), thermophilic mangrove palm Nypa and (sub)tropical dinoflagellate cyst Apectodinium, Cordosphaeridium and Kenleyia. This palynomorph assemblage is indicative of a marginal marine setting within a hot and humid climate. During the Middle Eocene, the diversity of dinocyst assemblage increased and a decrease in percentage of mangrove elements was observed in the Matanomadh and Panandhro mine sections of the Kutch Basin as compared to the Early Eocene sections of western India. Bloom of triserial planktic (Jenkinsina columbiana) and rectilinear benthic (Brizalina sp., Trifarina advena rajasthanensis) foraminifera indicates eutrophic conditions of deposition during the Late Lutetian-Early Bartonian in the lignite sections of the Kutch Basin which later changed to oligotrophic, open marine conditions towards the Bartonian (planktic E12 zone). This change to oligotrophic conditions coincides with a drastic increase in diversity of planktic foraminifera in the top portion of lignite mines of the Kutch Basin which may be correlated with the Kirthar-Wilson Bluff transgression event in the Bartonian observed across basins in India, Pakistan and Australia potentially linked to sea level rise around the Middle Eocene Climatic Optimum.
\end{abstract}

\section{Introduction}

\subsection{General introduction}

The Early and Middle Eocene exhibited a very warm climate, but towards the Late Eocene, the atmosphere cooled and shifted from hothouse to icehouse conditions (Zachos et al., 2001). The tropical temperatures during the Early Eocene increased by 5 to $6^{\circ} \mathrm{C}$, and there was little or no ice cover observed at the poles during these warming events (Pearson et al., 2001). There has been a plethora of records studied from the high latitudes with respect to microfossils and their change in size, diversity and abundance to adapt to the Paleogene warming events, especially the deep-sea drilling projects which have provided insight into continuous stratigraphic records (Clay Kelly et al., 1996; Kelly et al., 1998; Thomas and Shackleton, 1996; Arenillas et al., 1999; Giusberti et al., 2009; Alegret et al., 2010; Stassen et al., 2012; Zachos et al., 2001). The low-latitude records of the Paleogene which are stratigraphically continuous are comparatively sparse (Jaramillo et al., 2006, 2010; Zamagni et al., 2012; Pearson et al., 2001; Khanolkar and Saraswati, 2015; Cramwinckel et al., 2018; Naafs et al., 2018). Some of the low-latitude Eocene sections from Tanzania, India and Java have recently provided insight into temperatures in the tropics during the Eocene epoch (Evans et al., 2018). However, there is a need to produce robust records from well-preserved 
(a) Early Eocene ( $\sim 55 \mathrm{Ma}$ reconstruction)

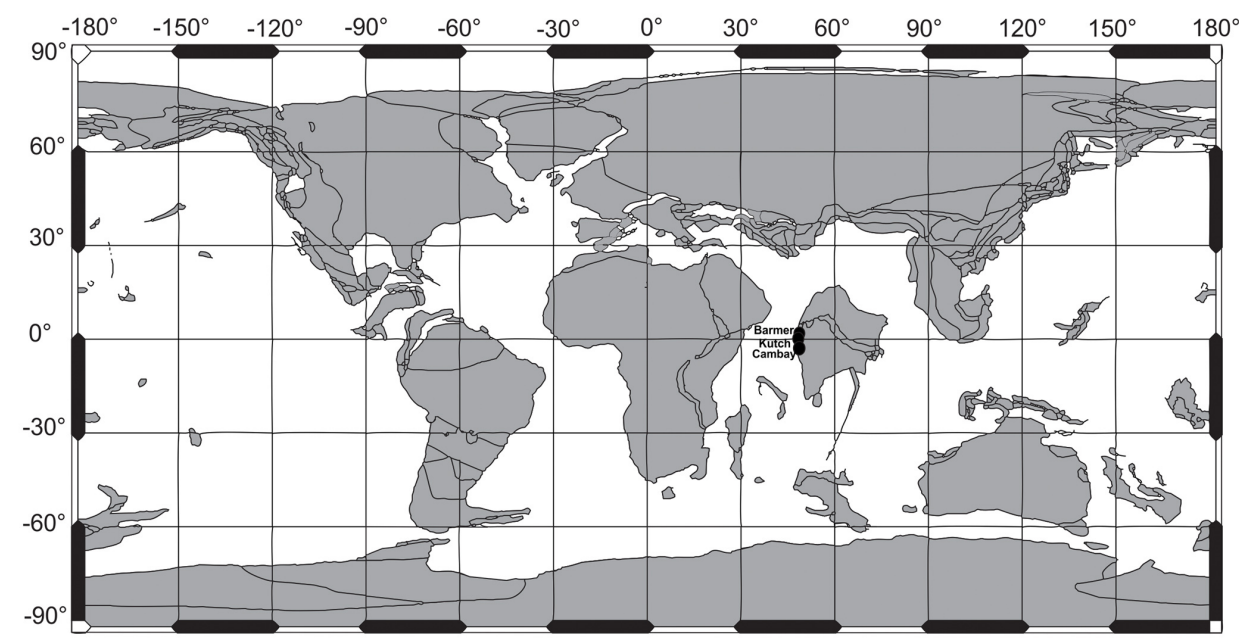

(b) Middle Eocene ( 40 Ma reconstruction)

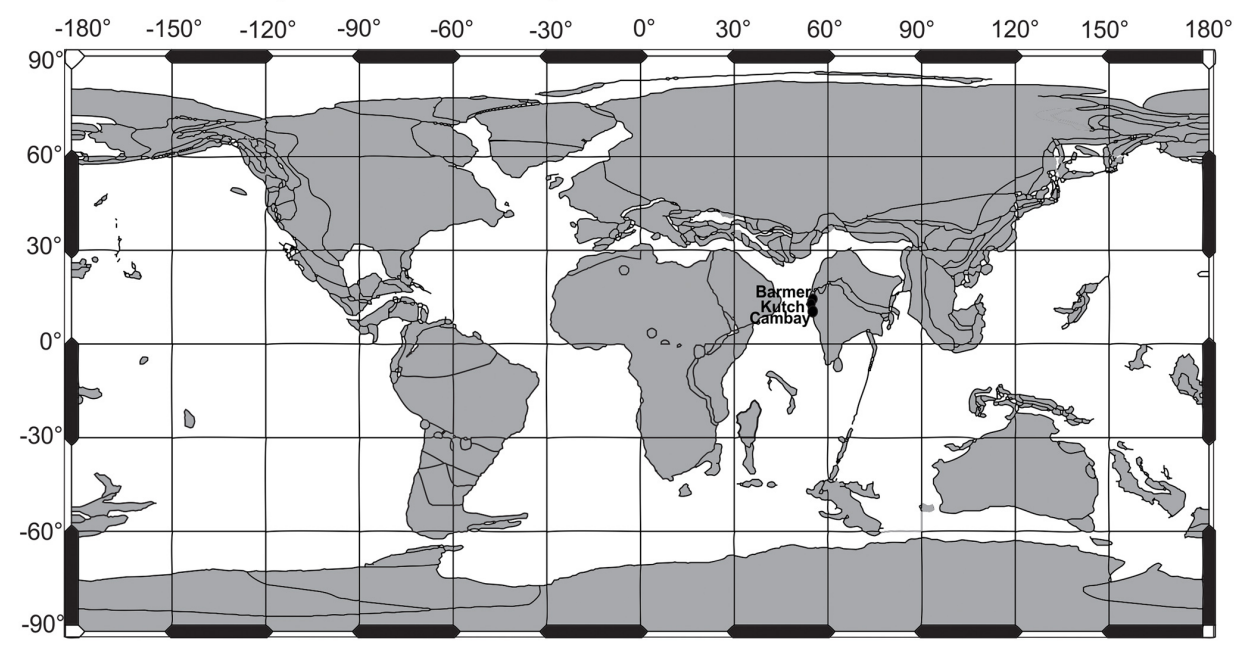

Figure 1. Paleoposition of the Cambay, Kutch and Barmer basins in India during the (a) Early Eocene and (b) Middle Eocene.

paleotropical Eocene sections to assess the response of flora and fauna to the greenhouse conditions which prevailed.

The Indian subcontinent (Fig. 1) has well-preserved records of Paleogene marine and continental sediments deposited along its western sedimentary basins ranging from the Eocene (shallow benthic zone: SBZ 5/6-SBZ 11 and SBZ 17; age: 56-49 Myr) to the Oligocene (SBZ 22b-SBZ 23; age: 28.1-23 Myr) (Saraswati et al., 2018). The humid hothouse during the Early Paleogene enhanced the development of tropical rainforests and gave rise to extensive development of lignite deposits in the Indian subcontinent. The sea level highstands which co-occur with these high temperatures, such as that in western India (Samanta et al., 2013; Prasad et al., 2013), probably facilitated the development and preservation of the lignite deposits (Sluijs et al., 2008). These lignite deposits were formed in the restricted marine basins and are coeval with the warming events in the Paleogene. The
Early Eocene lignite deposits were developed in the Cambay and Barmer basins, while the Middle Eocene lignite deposits are observed in the Kutch and Barmer basins. These lignite mine sections have recorded some of the warming events like Paleocene Eocene Thermal Maximum (PETM), Eocene Thermal Maximum 2 (ETM 2), Early Eocene Climatic Optimum (EECO) from the Cambay Basin and Middle Eocene Climatic Optimum (MECO) from the Kutch Basin (Samanta et al., 2013; Khanolkar et al., 2017; Clementz et al., 2011). The earlier works on these lignite mines emphasized the determination of paleoenvironmental conditions focusing on one microfossil group like pollen and spores or dinocysts or foraminifera (Sharma and Saraswati, 2015; Garg et al., 2008; Khanolkar et al., 2017). A lacuna exists in using an integrated approach to decipher the paleodepositional and paleoenvironmental conditions across the Early and Middle Eocene sections from paleotropical sites in India. 


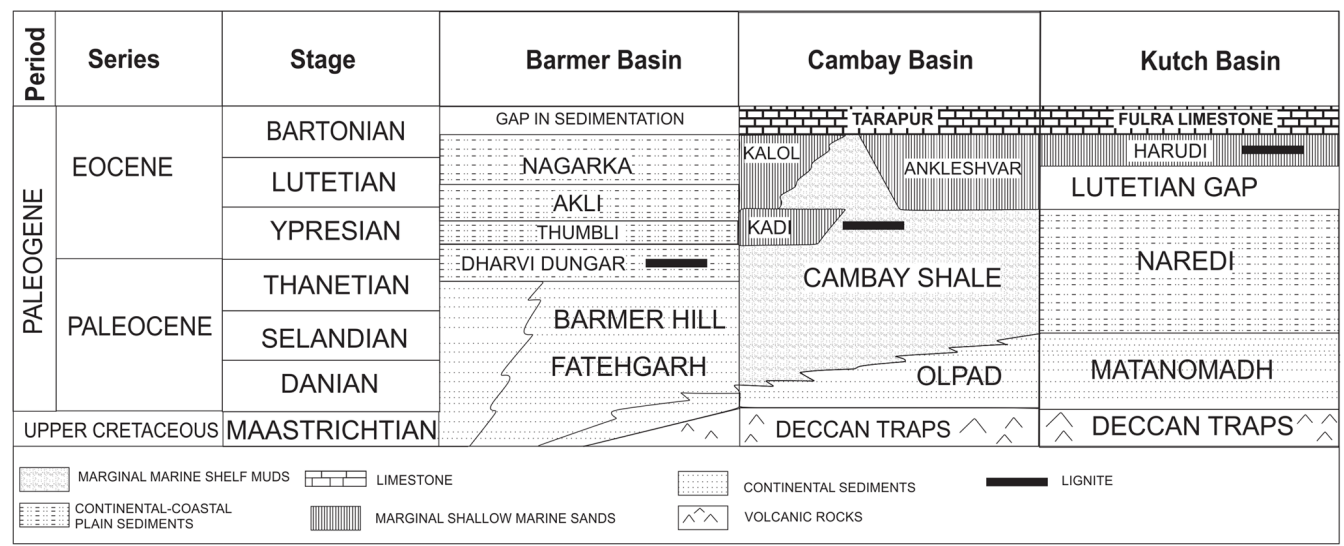

Figure 2. Eocene Stratigraphy of the Barmer, Cambay and Kutch basins in India.

In this work, we have addressed the similarities and differences observed in the paleodepositional and paleovegetational conditions from the Cambay, Kutch and Barmer basins during the tropical climate of the Early and Middle Eocene. For this, we have used an integrated approach by quantitatively analyzing various microfossil groups like foraminifera, pollen and spores, dinoflagellates and fungi. A holistic approach has made it possible to better determine the paleoenvironmental conditions from a restricted marine setting which depicts transitional environments and is comprised of various groups of microfossils belonging to both continental and open marine ecosystems. For our present study, we have chosen four lignite mine sections: (1) Surkha lignite mine section (Cambay Basin), (2) Giral lignite mine section (Barmer Basin), (3) Matanomadh (Kutch Basin) and (4) Panandhro lignite mine section (Kutch Basin).

\subsection{Eocene lignites from western Indian basins}

The mineable lignite deposits of Eocene age are found along the three sedimentary basins of western India viz. Barmer, Kutch and Cambay. Various well-preserved vertebrate fossils belonging to perissodactyls, artiodactyls, insectivores, proteutherians, apatotherians, marsupials, rodents and microfossils like dinoflagellates, pollen and spores, and foraminifera have been discovered from these lignite mine sections, rendering them essential from a stratigraphic point of view (Bajpai et al., 2005; Khanolkar and Saraswati, 2015; Garg et al., 2008).

\subsubsection{Rajasthan Basin}

The Rajasthan Basin consists of a geological record from Archean to recent times. Within the Rajasthan Basin, three sub-basins, namely the Barmer, Jaisalmer and BikanerNagaur (K. Kumar et al., 2007), exist and cover an area of approximately $120000 \mathrm{~km}^{2}$. The Barmer Basin is comprised of sediments from Precambrian to Middle Miocene age. The
Jagmal Group, which is of Eocene age, lies unconformably over the Mallinath Group of Late Cretaceous-Late Paleocene age. The Jagmal Group is comprised of shales, lignites and sandstones. The Giral lignite mine belongs to the Dharvi Dungar Formation within the Jagmal Group and is of Early Eocene age (Fig. 2). The subsurface stratigraphy has established that there is a second and younger level of lignite (Akli Formation) of Middle Eocene age in the basin that is seismically well separated (Dolson et al., 2015).

\subsubsection{Cambay Basin}

The Cambay Basin is comprised of Paleogene sediments overlain by Quaternary alluvium. The Paleogene sequence rests unconformably over the Deccan flood basalts, ranges in age from Paleocene to Plio-Pleistocene and has been deposited by various transgressive-regressive cycles. The oldest Paleogene rocks are comprised of the Olpad Formation, which is unconformably overlain by the Cambay Formation (Paleocene-Early Eocene) (Fig. 2) (Chandra and Chowdhary, 1969). The Cambay Formation is best exposed along the open-cast lignite mines and has yielded rich and diverse fauna of various fossil groups. The lignite mine sections of Vastan and Valia have reported the presence of hyperthermal events including PETM and EECO (Samanta et al., 2013; Clementz et al., 2011). The Surkha lignite mine section is examined in this study.

\subsubsection{Kutch Basin}

The Kutch Basin is a pericratonic rift basin trending laterally beside the western margin of India and developed during the separation of India from Gondwanaland in the Late Triassic (Biswas, 1992). A complete stratigraphic succession from Paleogene to Quaternary, with records of marine transgression and several stratigraphic breaks, was recorded in the basin (Biswas, 1992). A significant part of the Tertiary sequence is observed in the offshore region of the Kutch 


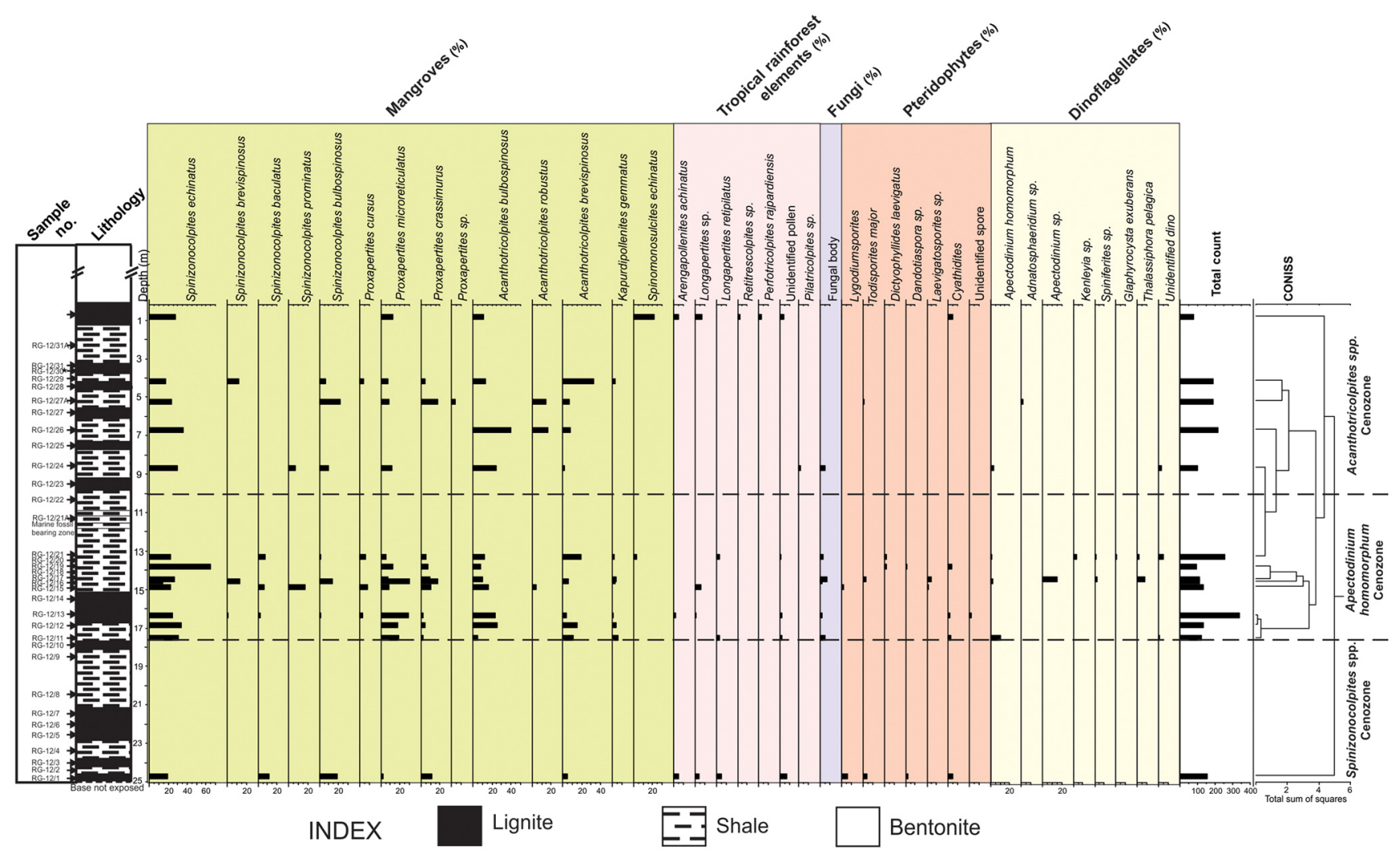

Figure 3. Percentage distribution of palynomorphs in the Giral lignite mine section, Barmer Basin.

Basin, whereas on land, these Tertiary sections are restricted to the western part. The Eocene sections mainly constitute shales, claystones and limestones deposited in lagoonal to shallow marine environments. These Eocene sediments have preserved large groups of faunal assemblages including foraminifera, dinocysts, pollen and spores (Khanolkar and Saraswati, 2015; Sharma and Saraswati, 2015; Garg et al., 2008). The Paleogene succession of the Kutch is comprised of five formations. These include Matanomadh Formation, Naredi Formation, Harudi Formation, Fulra limestone and Maniyara Fort Formation) (Fig. 2) (Biswas, 1992; Saraswati et al., 2018).

\subsection{Previous stratigraphic works}

The Cambay, Kutch and Rajasthan basins have been previously investigated by various workers to decipher the age of the mine sections.

\subsubsection{Rajasthan Basin}

Dolson et al. (2015) updated the stratigraphy of the Barmer Basin in Rajasthan using the data acquired from 420 wells, $4 \mathrm{~km}$ of conventional core and 2-D and 3-D seismic mapping techniques. The age of the lignite mine section of the Giral was earlier thought to be of Late Paleocene-Early Eocene
(Rana et al., 2005). However, the recent work by Dolson et al. (2015) has updated it to be of Early Eocene age.

\subsubsection{Cambay Basin}

The Early Eocene (Ypresian) palynomorph taxa from the Surkha mine consist of Polysphaeridium subtile, Homotryblium pallidum, Retipollenites confusus, Arengapollenites achinatus and Tribrevicolporites eocenicus reported from lignite mine sections of Rajpardi and Vastan from the Cambay Basin (Kumar, 1994; Samant and Phadtare, 1997; Mandal and Guleria, 2006; Tripathi and Srivastava, 2012; Rao et al., 2013). This evidence further corroborates the existence of coeval deposition and analogous paleoenvironment. The age of the Vastan mine section is inferred to be Early Eocene, given the presence of Nummulites burdigalensis burdigalensis (Punekar and Saraswati, 2010).

\subsubsection{Kutch Basin}

The age of lignites from the Kutch Basin was earlier thought to be Early Eocene (Biswas, 1992). However, recent work has revised the stratigraphy of the Kutch Basin, and the current understanding states that the lignites belong to Middle Eocene age (Saraswati et al., 2018, 2014). In a marginal marine environment, it is essential to infer the age of the 


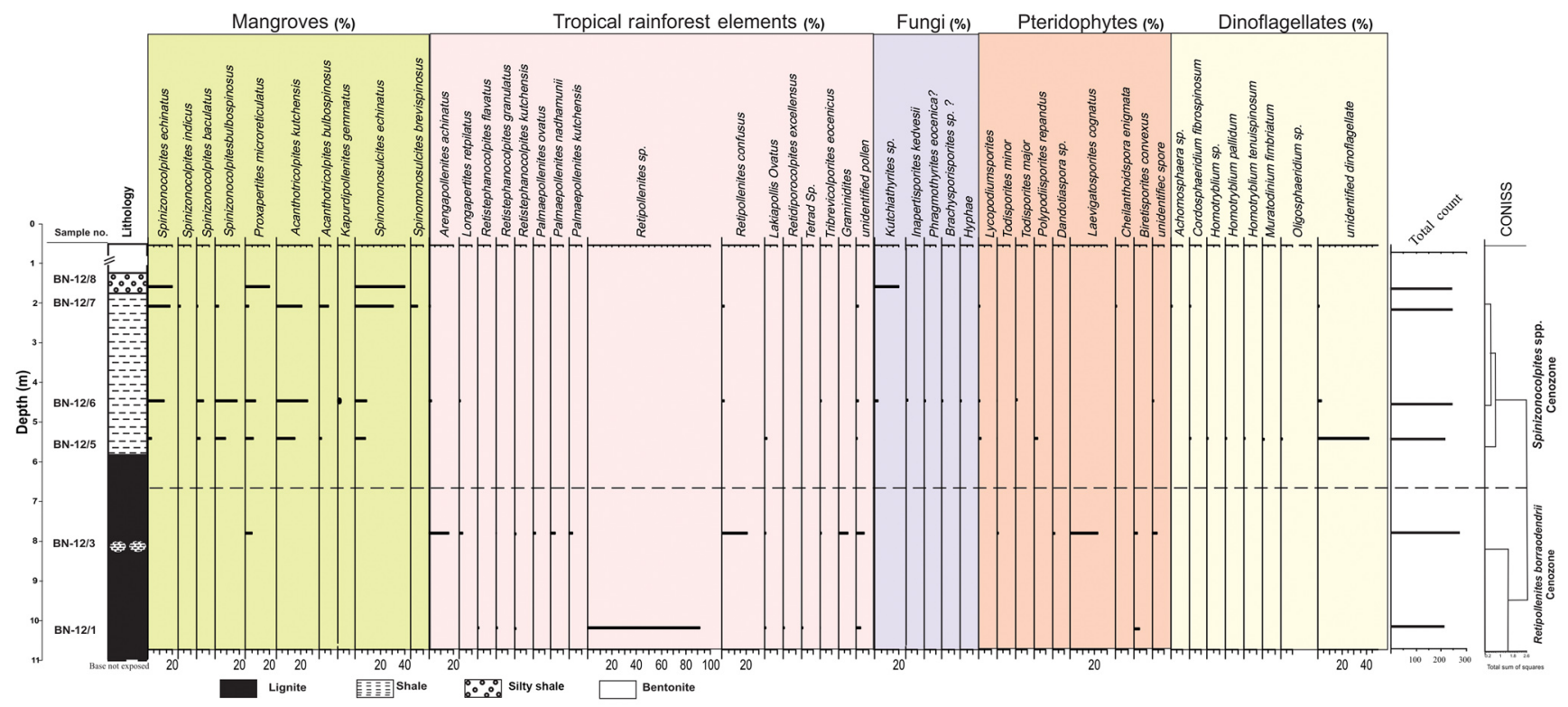

Figure 4. Percentage distribution of palynomorphs in the Surkha lignite mine section, Cambay Basin.

sequence using an integrated approach which involves the study of various group of microfossils like palynomorphs and foraminifera (Sharma and Saraswati, 2015). The shales deposited above the lignite seams of the Panandhro and Matanomadh mines consists of foraminifera such as Nummulites spectabilis, Linderina kutchensis and Halkyardia minima, which are typically found in the Middle Eocene in other sections of the Kutch Basin and correspond to Bartonian age (SBZ 17). There is no break in sedimentation or unconformity observed between the lignites and the overlying shales of Bartonian age. It can thus be stated that the lignites are of Bartonian age or could have ranged down to latest Lutetian.

\section{Materials and methods}

\subsection{Materials}

The field area is comprised of lignite mine sections from three different sedimentary basins (Cambay, Kutch and Rajasthan) alongside the western margin of India (Fig. 1; Sect. S1 in the Supplement).

\subsubsection{Rajasthan Basin}

For the current study, we collected 33 samples from $26 \mathrm{~m}$ exposure of the open-cast lignite mine of the Giral from the Barmer sub-basin. The profile constitutes alternations of shale and lignite beds. The sample positions are marked in the lithocolumn illustrated in Fig. 3 (refer to Sect. S1 in the Supplement).

\subsubsection{Cambay Basin}

The Surkha lignite mine section is equivalent to the subsurface Cambay Shale Formation and belongs to Early Eocene. We have collected eight samples from the bottom to top of the mine section, and their positions are marked within the lithocolumn (Fig. 4; Sect. S1 in the Supplement). The mine section is comprised mainly of lignites and shales. Around $5 \mathrm{~m}$ thick brown colored friable lignite horizon is overlain by marine shale, which gradually grades into silty shale at the top. The whole lignite-bearing sequence is covered by $20 \mathrm{~m}$ thick bentonite clay.

\subsubsection{Kutch Basin}

From the Kutch Basin, we have collected samples from the Matanomadh mine section (23 samples from $10 \mathrm{~m}$ exposure of lignites, shales and mudstones; Fig. 5; Sect. S1 in the Supplement) and Panandhro lignite mine (47 samples from $55 \mathrm{~m}$ exposure of lignite and shale sections; Fig. 6; Sect. S1 in the Supplement).

\subsection{Methodology}

\subsubsection{Palynomorphs separation and slide preparation}

For palynomorph analysis, we processed samples from all four mine sections. Initially, we treated $20 \mathrm{~g}$ of the dry sample with dilute $\mathrm{HCl}(30 \%)$ for removal of carbonates. The residue left was consecutively treated with hydrofluoric (HF) acid (38\%) for removal of silica and $\mathrm{HNO}_{3}$ for removal of sulfides and sulfates. Deionized water was utilized to neutralize the samples which were wet sieved $(10-250 \mu \mathrm{m}$ sieve 


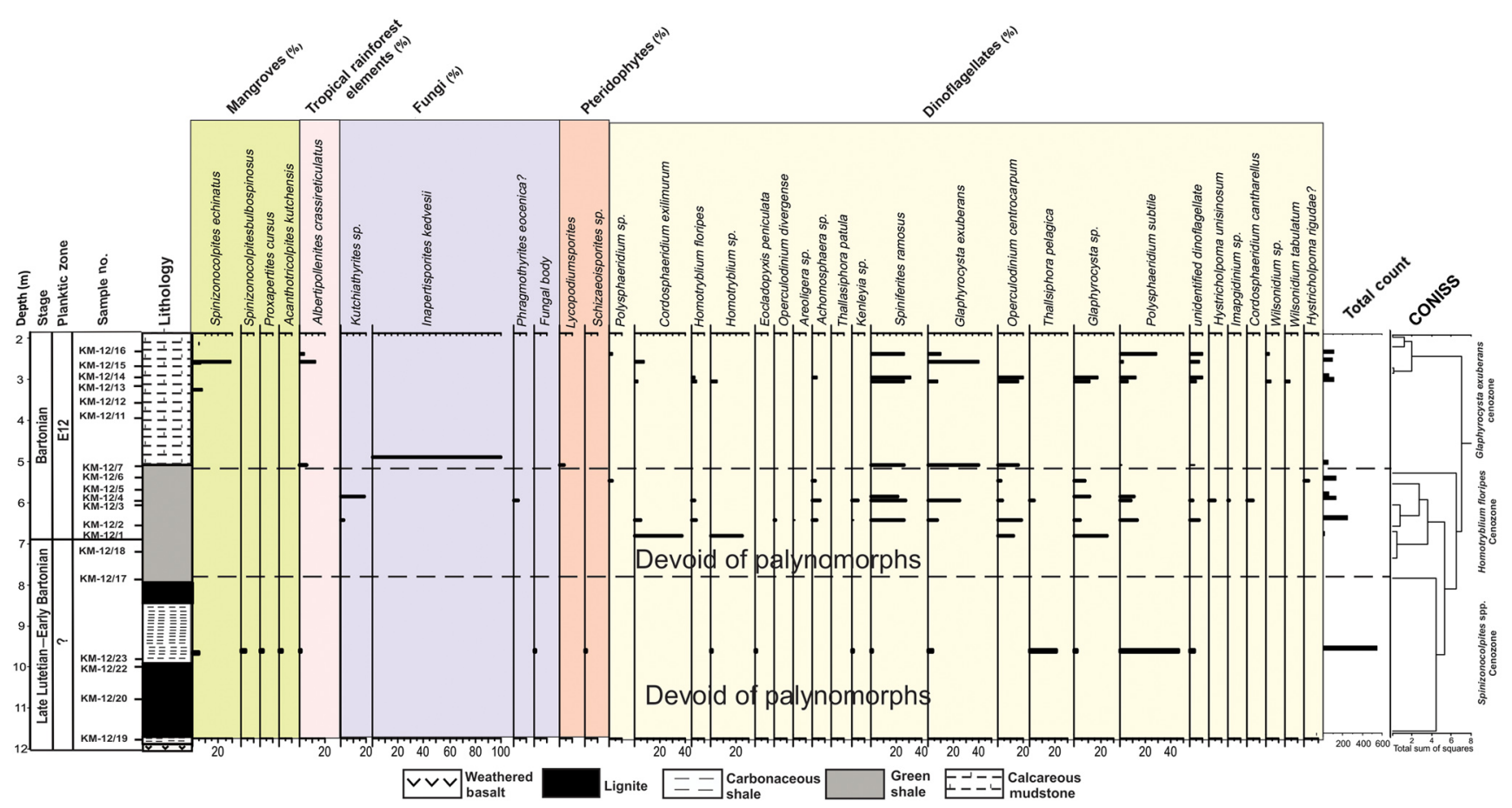

Figure 5. Percentage distribution of palynomorphs in the Matanomadh lignite mine section, Kutch Basin.

size). We used Safranin O to stain the residue. Polyvinyl alcohol and Canada balsam were used for the preparation and mounting of the slides. From each sample which contained of palynomorphs, we have counted at least 200 palynomorphs, which we considered as the total count. Figures 3-6 exhibit plots of percentage variation of palynomorphs (refer to Sect. S2 in the Supplement). We have also grouped various categories of palynomorphs and their distributions in Figs. 7-10. The palynomorph distribution diagrams have been further divided into zones by stratigraphically constrained cluster analysis using CONISS (Grimm, 2004) available in Tilia TG View 2.0.2 software (Grimm, 2004) in conjugation with the changes in the percentage of some important taxa. Plates 1-2 illustrate the representative palynomorph taxa. The ecological preferences for palynomorph taxa are given in Sect. S3 in the Supplement.

\subsubsection{Foraminiferal analysis}

We have used around $20 \mathrm{~g}$ of sample (shales and mudstones) for processing. The sample was treated with $\mathrm{H}_{2} \mathrm{O}_{2}$ initially for removal of any organic material. The residue left was then mixed with water and heated after adding $\mathrm{Na}_{2} \mathrm{CO}_{3}$ to it for half an hour, following which the residue was washed over a $>63 \mu \mathrm{m}$ sieve. The washed residue was dried at $60^{\circ} \mathrm{C}$ temperature in an oven. From each representative sample obtained by using a microsplitter, a minimum of 300 foraminifera were picked and represented as the "total foraminifera number". We have used the TILIA 2.0.2 soft- ware by Grimm (2004) to plot the percentage distribution data of each species. The foraminifera percentage distribution data for the sections are provided in Fig. 11. The identification of foraminifera was carried out by following the works of Murray and Wright (1974), Singh and Kalia (1970), Kalia (1978), Loeblich Jr. and Tappan (2015) and Pearson et al. (2005). The paleoenvironment and paleodepositional analysis has been carried out by using foraminiferal morphogroups (Nagy, 1992; Preece et al., 1999; Nigam et al., 2007; Reolid et al., 2008; Singh et al., 2015). Using their technique to record the foraminiferal morphogroups, we have divided the smaller benthic foraminifera further into the rectilinear benthic foraminifer (RBF) morphogroup, consisting of foraminifera with uniserial, biserial or triserial chamber arrangements, and its percentage is used to indicate benthic oxygenation conditions. The illustration of significant foraminifera taxa is shown in Plate 3.

\section{Results}

\subsection{Biostratigraphy of the study areas}

The age of lignite mines of the Surkha (Cambay), Panandhro and Matanomadh (Kutch) has already been established earlier. However, the age of the Giral mine section of the Barmer Basin was determined in this study using palynomorphs.

For the Rajasthan Basin, the palynological analysis of the Giral mine section (Barmer Basin) indicates an Early Eocene age. Dinocysts are present in a few shale layers within the 


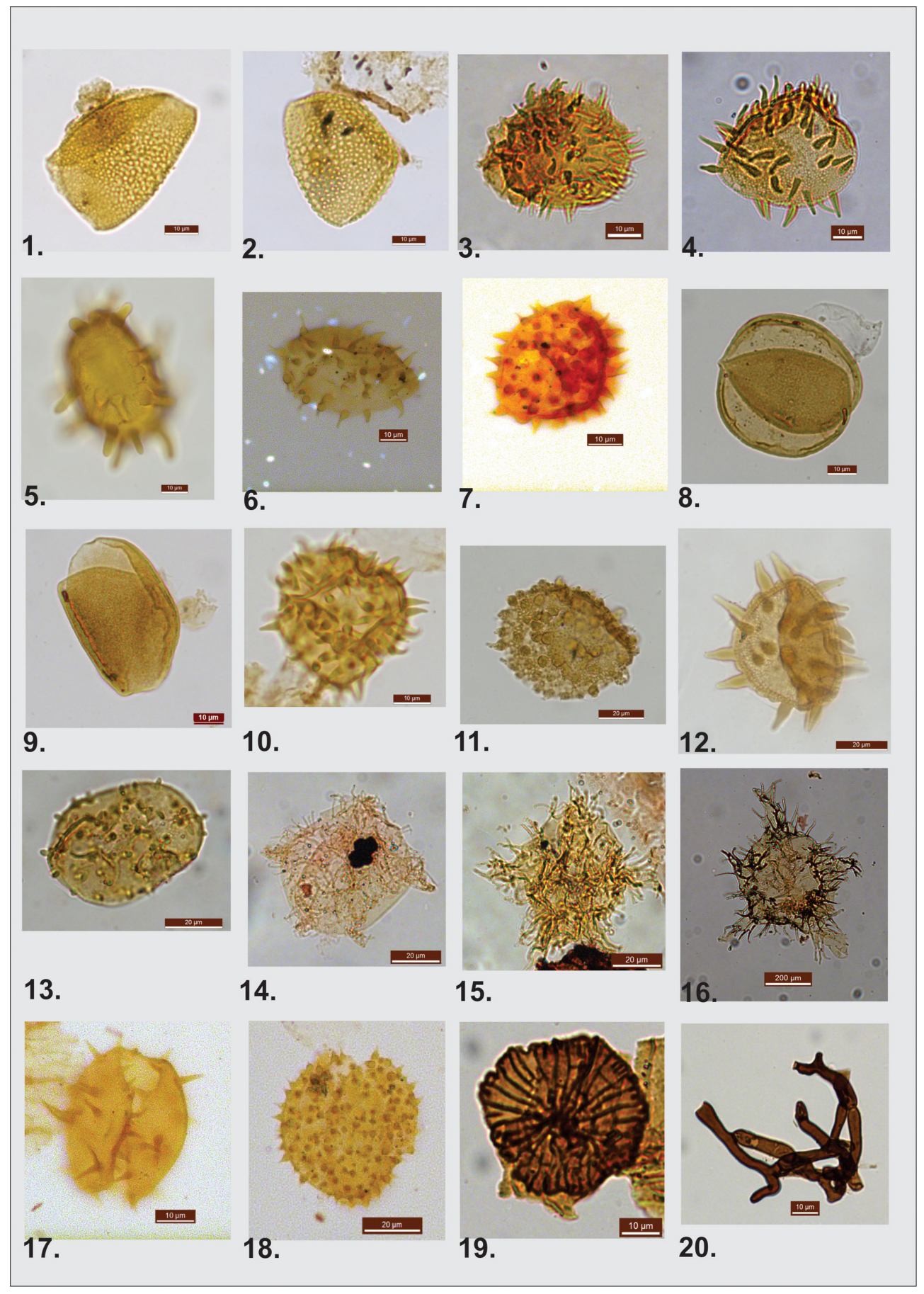

Plate 1. The palynomorph assemblage from Early Eocene sections: panels (1) and (2) are Longapertites retipilatus. Panels (3), (4) and (5) are Spinizonocolpites prominatus. Panels (6) and (7) are Spinizonocolpites bulbospinosus. (8) Proxapertites microreticulatus. (9) Longapertites retipilatus. (10) Acanthotricolpites bulbospinosus. (11) Kapurdipollenites gemmatus. (12) Spinizonocolpites baculatus. (13) Spinizonocolpites brevispinosus. (14) Apectodinium quinquelatum. (15) Apectodinium paniculatum. (16) Apectodinium paniculatum. (17) Arengapollenites achinatus. (18) Acanthotricolpites kutchensis. Panels (19) and (20) are fungal elements. 


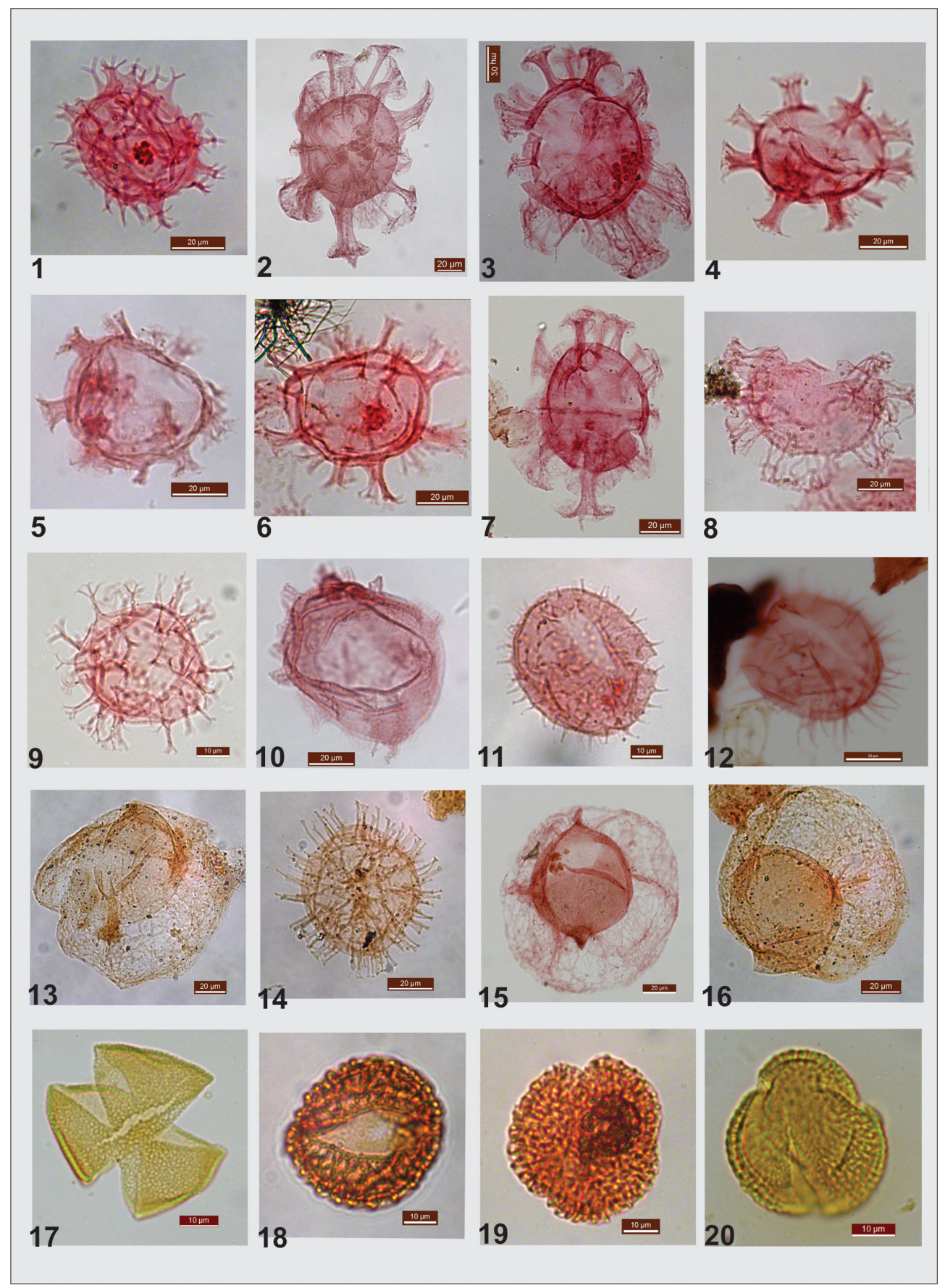

Plate 2. The palynomorph assemblage from Middle Eocene lignite mine sections of the Panandhro and Matanomadh: panel (1) is Achomosphaera sp. Panels (2) and (3) are Cordosphaeridium exilimurum. Panels (4), (5) and (6) are Homotryblium floripes. (6) Glaphyrocysta exuberans. (7) Cordosphaeridium cantharellus. (8) Glaphyrocysta exuberans. (9) Spiniferites ramosus. (10) Kenleyia sp. Panels (11) and (12) are Operculodinium centrocarpum. (13) Thalassiphora pelagica. (14) Polysphaeridium subtile. (15) Thalassiphora fenestrata. (16) Thalassiphora pelagica. (17) Dipterocarpuspollenites retipilatus. Panels (18) and (19) are Albertipollenites crassireticulatus. (20) Tricolpites sp. 


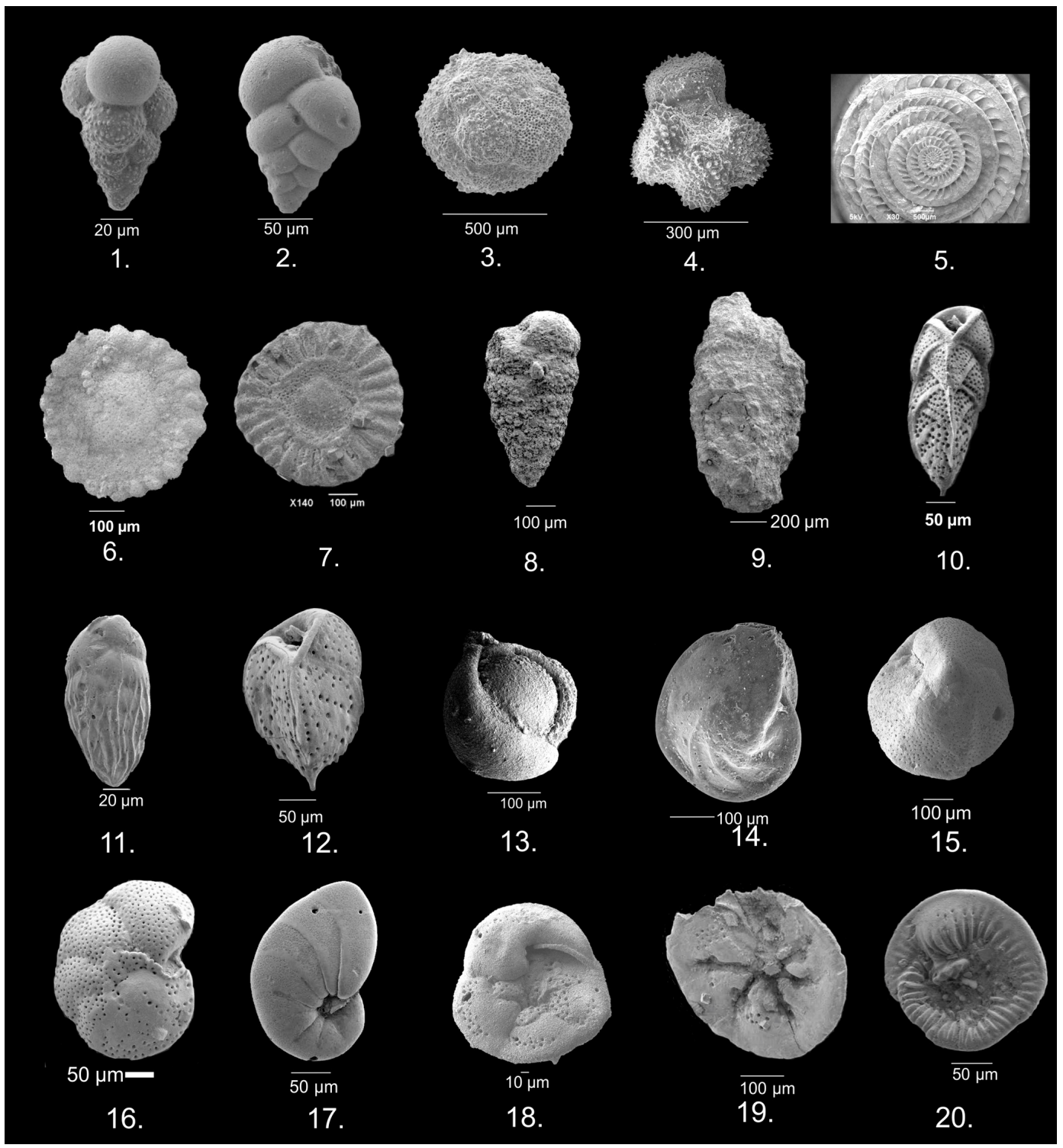

Plate 3. The foraminiferal assemblage from the Panandhro and Matanomadh lignite mines. (1) Jenkinsina columbiana. (2) Streptochilus martini. (3) Orbulinoides beckmanni. (4) Acarinina topilensis. (5) Nummulites obtusus. (6) Linderina kutchiensis. (7) Halkyardia minima. (8) Textularia halkyardia. (9) Miliammina sp. (10) Trifarina advena rajasthanensis. (11) Brizalina sp. (12) Reusella sp. (13) Triloculina architectura. (14) Robulus sp. (15) Cibicides punjabensis. (16) Cibicides sp. (17) Florilus sp. (18) Pijpersia coronaeformis. (19) Eponides sp. (20) Glabratella ubiqua.

Giral lignite section. The dinocyst assemblage is comprised of Apectodinium homomorphum, Adnatosphaeridium sp., Glaphyrocysta exuberans, Kenleyia sp. and Thalassiphora pelagica. Although most of the genera recovered in the analysis are long-ranging, the presence of rich and diverse Apectodinium assemblages all along the profile suggests that the lignites were deposited during the Ypresian (Garg et al., 2008; Crouch et al., 2003). This matches with the age given by Dolson et al. (2015) of the Giral lignite mine section and is thus reconfirmed to be the Early Eocene.

\subsection{Stratigraphic variation in percentage of palynomorphs in individual mine sections}

\subsubsection{Giral mine}

Overall, 33 samples from the Giral lignite mine were processed and studied for the palynomorph assemblage (Fig. 3). The mine section is rich in both terrestrial and marine flora. Some of the palynoflora recovered are Spinizonocolpites baculatus, Dandotiaspora telonata, Palmaepollenites plicatus, Longapertites retipilatus and Acanthotricolpites. Based on the distribution and abundance of palynomorphs, the stud- 


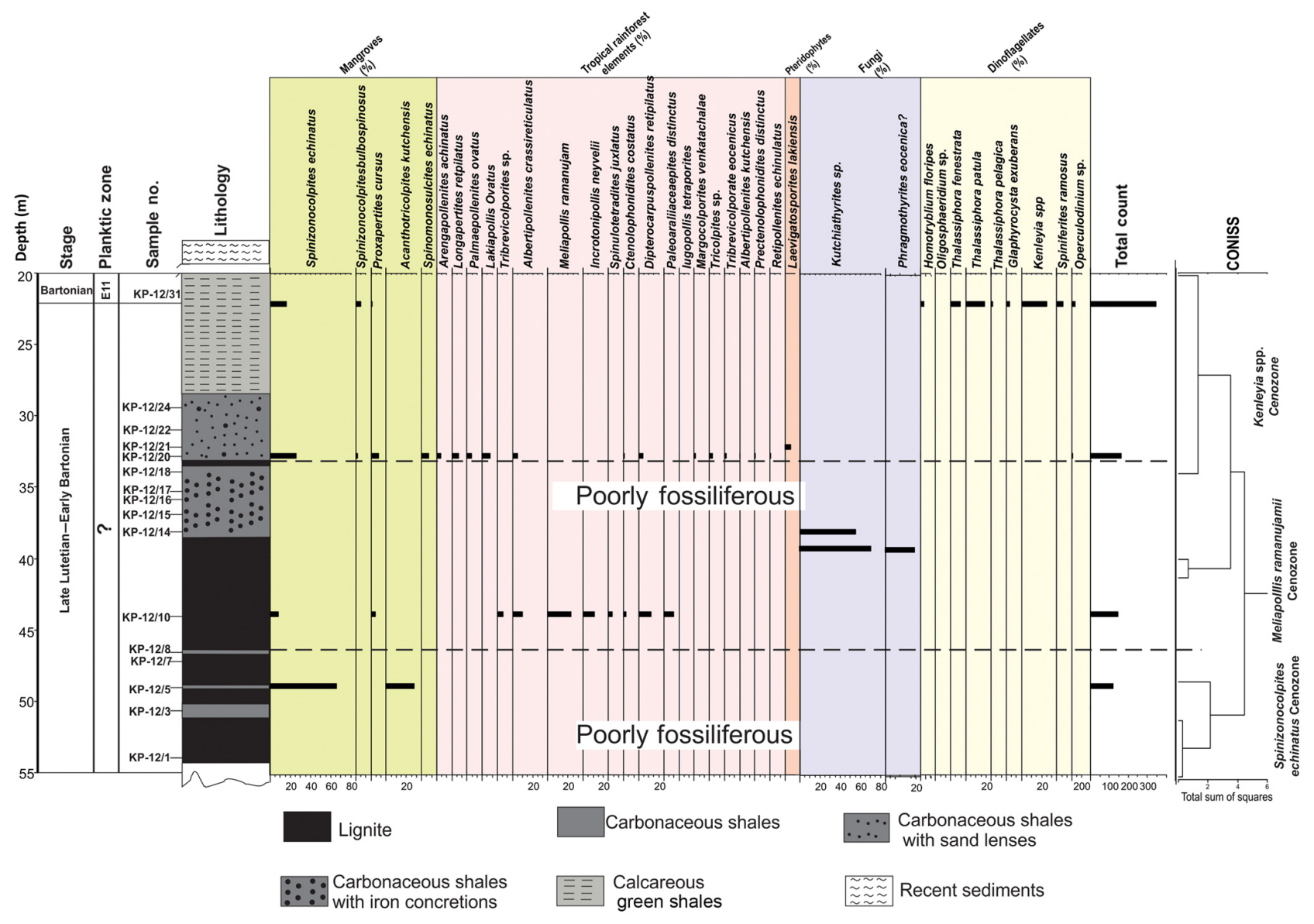

Figure 6. Percentage distribution of palynomorphs in the Panandhro lignite mine section, Kutch Basin.

ied succession of the Giral lignite mine has been divided into three cenozones.

In the stratigraphic order, they are

\section{Spinizonocolpites spp. cenozone.}

\section{Lithology}

The lowermost lignite and intervening shale units. Thickness is about $7 \mathrm{~m}$.

\section{Position}

From sample no. RG-12/1 to RG-12/10.

\section{Important taxa}

In relation to the overlying assemblage, the litho-unit of this cenozone is poor in pollen yield. All the samples were studied but only sample number RG-12/1 yielded enough palynomorphs for quantification. Spinizonocolpites and Proxapertites mark their appearance in this cenozone; however, these taxa could not be quantified due to their low abundance. The cenozone is named after the presence of Spini- zonocolpites pollen grain which was represented throughout the cenozone. The other essential taxa recovered are Spinizonocolpites baculatus, S. bulbospinosus, Proxapertites microreticulatus, P. crassimurus, Acanthotricolpites brevispinosus, Arengapollenites achinatus, Longapertites retipilatus, etc.

\section{Lower limit}

The lower limit is not traceable.

Upper limit

The upper contact is the overlying $70 \mathrm{~cm}$ thick shale bed.

\section{Apectodinium homomorphum cenozone}

\section{Lithology}

Lignite- and marine-fossil-bearing shale unit. Thickness is about $8 \mathrm{~m}$. 


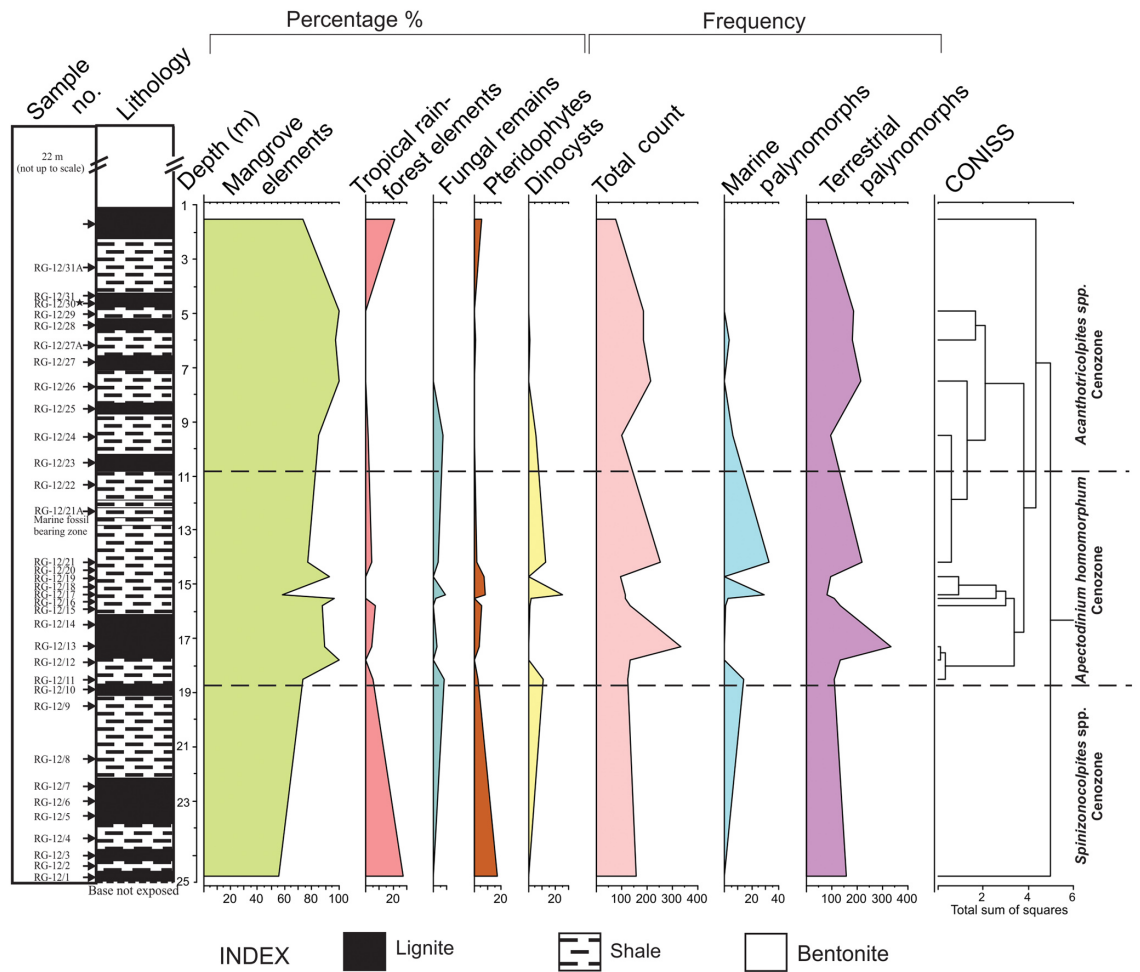

Figure 7. Distribution of a group of palynomorph taxa in the Giral lignite mine, Barmer Basin.

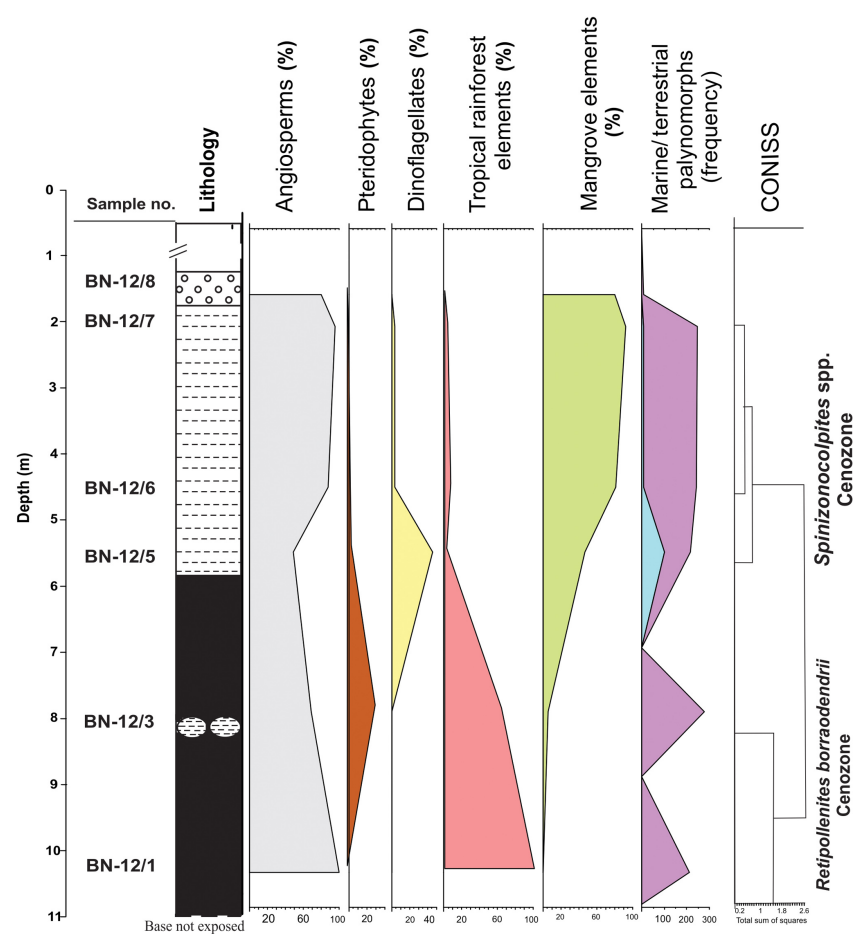

Figure 8. Distribution of a group of palynomorph taxa in the Surkha lignite mine, Cambay Basin.
Position

From sample no. RG-12/11 to RG-12/22.

Important taxa

This cenozone is comprised of marine and terrestrial palynomorphs. The cenozone is named after the first occurrence of stratigraphically important dinocyst Apectodinium homomorphum. The characteristic feature of this cenozone is the high percentage of Spinizonocolpites echinatus, S. baculatus, S. bulbospinosus, Proxapertites microreticulatus, $P$. crassimurus, Acanthotricolpites brevispinosus and A. bulbospinosus. The other essential taxa recovered are Arengapollenites achinatus, Longapertites retipilatus, Dandotiaspora telonata, Lygodiumsporites sp., Todisorites major. Kapurdipollenites gemmatus made its first appearance along with dinocysts (Apectodinium paniculatum, Kenleyia spp., Thalassiphora pelagica and Glaphyrocysta exuberans, Adnatosphaeridium sp.) in this zone.

Lower limit

First appearance of Kapurdipollenites and Apectodinium homomorphum. 


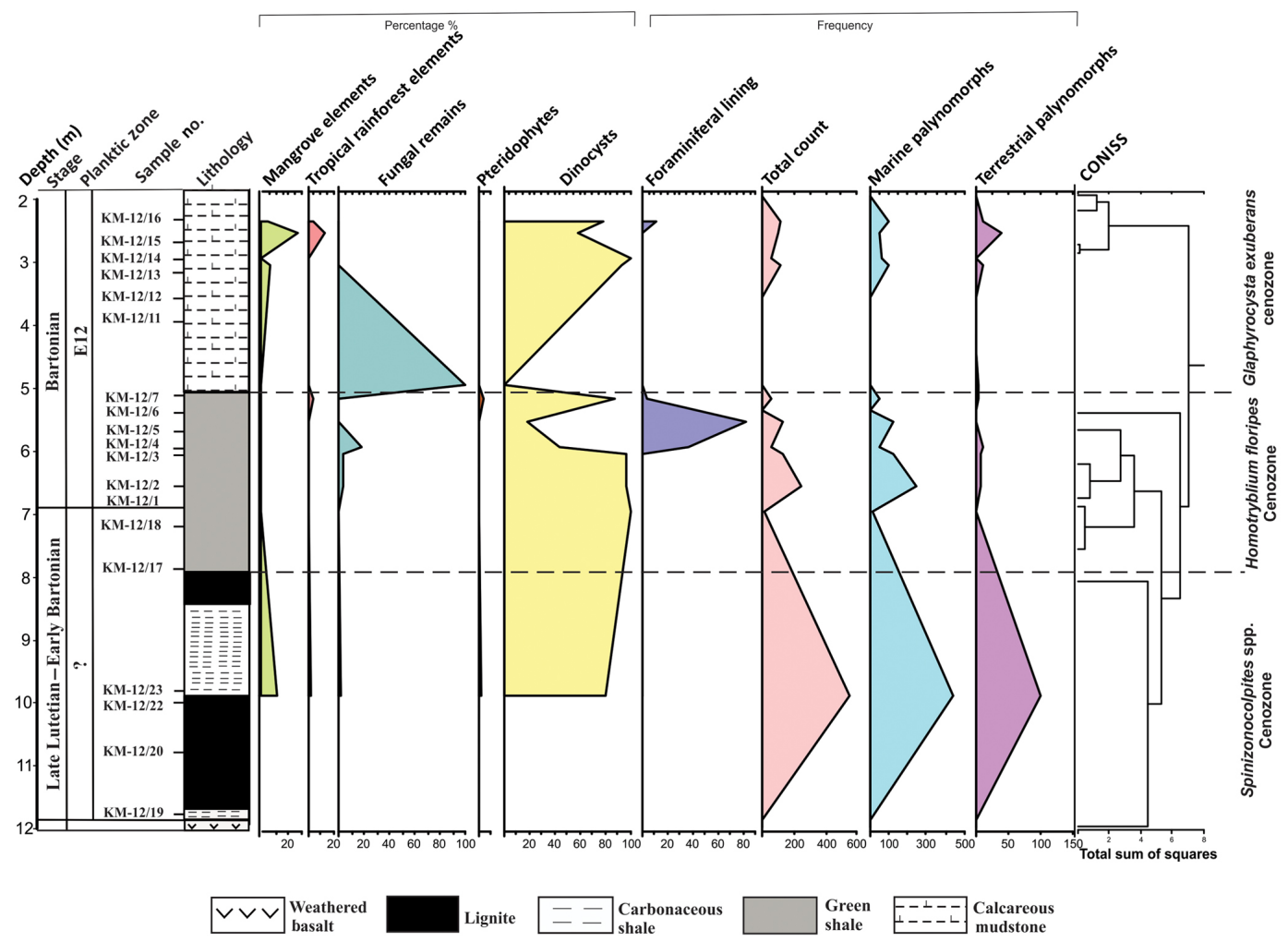

Figure 9. Distribution of a group of palynomorph taxa in the Matanomadh lignite mine, Kutch Basin.

\section{Upper limit}

Significant increase in the percentage of Acanthotricolpites spp.

Acanthotricolpites spp. cenozone

\section{Lithology}

Alternate lignite and shale beds. Thickness is about $10 \mathrm{~m}$.

\section{Position}

From sample no. RG-12/22 to RG-12/33.

\section{Important taxa}

This cenozone is comprised of a high percentage of different species of Acanthotricolpites, along with pollen grains of Spinizonocolpites and Proxapertites. It is similar to the Apectodinium homomorphum cenozone in the distribution of palynomorphs with a reduction in marine taxa and an increment in the number of Acanthotricolpites spp. The cenozone is named after the rise in the percentage of various species of Acanthotricolpites genera. The other essential taxa are Spinizonocolpites echinatus, S. brevispinosus, S. baculatus, S. bulbospinosus, Proxapertites cursus, P. microreticulatus, P. crassimurus, Acanthotricolpites brevispinosus, A. ro- bustus, A. bulbospinosus, Arengapollenites achinatus, Longapertites retipilatus and Kapurdipollenites gemmatus. The percentage of dinocysts is decreasing compared to the earlier zone.

\section{Lower limit}

Lignite seam above the marine-fossil-bearing shale unit.

\section{Upper limit}

The overlying bentonite just above the last lignite seam in the exposure.

\subsubsection{Surkha mine}

Out of the eight samples, only samples from five horizons yielded palynomorphs. Palynomorphs ascribed as pteridophytic spores have been assigned to six genera and eight species, while 12 genera and 22 species have been identified as angiosperm pollen. Spores, hyphae and microthyraceous fruiting bodies constitute the fungal remains. The angiosperms dominate the assemblage with a low percentage of pteridophytes. The gymnospermous pollen grains are absent in the assemblage. The assemblage has been divided into two cenozones viz. (i) Retipollenites borrasodendrii cenozone and (ii) Spinizonocolpites spp. cenozone. The lower- 


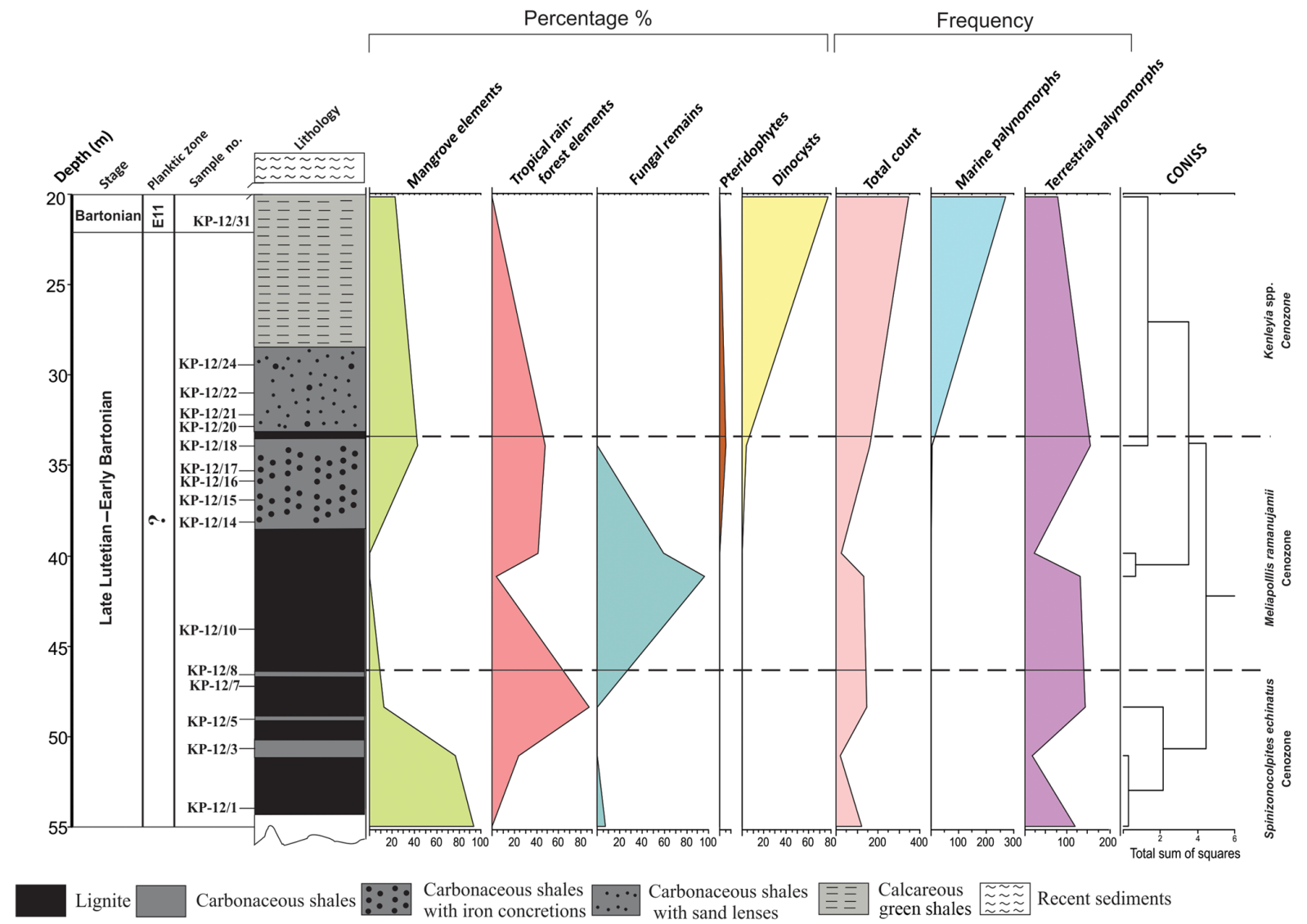

Figure 10. Distribution of a group of palynomorph taxa in the Panandhro lignite mine, Kutch Basin.

most part of the section is comprised of tropical rainforest elements, whereas mangrove elements dominate the section towards the upper part. The angiosperm pollen of the Arecaceae family is dominant over all the other groups of palynomorphs. The cenozones in the Surkha mine are demarcated in Fig. 4.

\section{Retipollenites borrasodendrii cenozone}

\section{Lithology}

Lignite with shale intercalations at $3 \mathrm{~m}$ from the base. Thickness is about $4 \mathrm{~m}$.

\section{Position}

From sample no. BN 12/1 to BN 12/3.

\section{Important taxa}

This cenozone is marked by a high percentage of Retipollenites borrasodendrii (up to $91 \%$ ) and Retipollenites confuses which does not occur in the younger zone. Other significant taxa represented in the cenozone are Tribrevicolporites eocenicus, Lakiapollis ovatus, Arengapollenites achinatus,
Retistephanocolpites spp., Acanthotricolpites kutchensis and Todisporites minor.

Lower limit

The lower limit is not traceable.

Upper limit

Significant decrease in the percentage of Retipollenites.

Spinizonocolpites spp. cenozone

\section{Lithology}

Comprised of carbonaceous shales. Thickness is about $4 \mathrm{~m}$.

\section{Position}

From sample no. BN 12/5 to BN 12/7.

This cenozone is marked by an appreciable decrease in the percentage of Retipollenites spp. (from $91 \%$ to $2 \%$ ), the first appearance of Spinizonocolpites echinatus and dinocysts. The cenozone is comprised of arecaceous pollen Spinizonocolpites, Proxapertites, Neocouperipollis, Retimonosulcites 

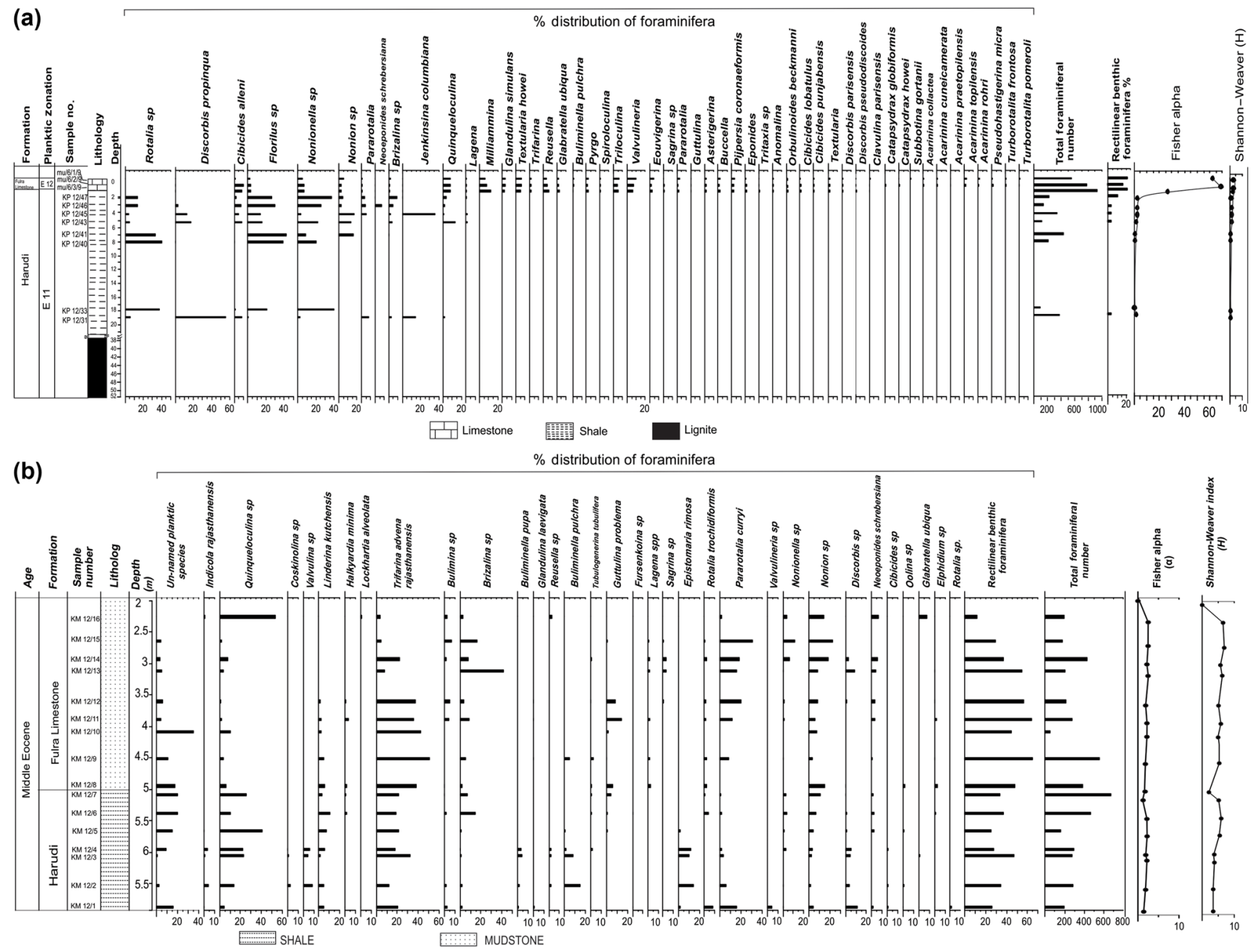

Figure 11. Percentage distribution, diversity indices and RBF morphogroup of foraminifera in samples from the (a) Panandhro lignite mine and (b) Matanomadh lignite mine section in the Kutch Basin of western India.

and Acanthotricolpites. The pollen ascribed to Spinizonocolpites (about $21 \%$ ) dominates the assemblage; hence, the cenozone is named after it. Some of the other taxa found are Arengapollenites achinatus, Tribrevicolporites eocenicus, Longapertites sp., Retipollenites spp., Kutchiathyrites spp. and Phragmothyrites spp.

Lower limit

Appearance of dinoflagellates.

Upper limit

Bentonite layer.

\subsubsection{Matanomadh mine}

Palynological analysis of 23 samples from the Matanomadh mine section was accomplished. The lower part of the mine section includes pollen and spores with sparse dinocysts. Well-preserved and abundant dinocysts characterize the top part of the section. The entire lithocolumn is dominated by dinocysts, followed by the pollen of the Arecaceae family (Spinizonocolpites, Acanthotricolpites, Proxapertites). Based on variations in the percentage of the different species, three cenozones were identified (Fig. 5) in the assemblage as follows:

\section{Spinizonocolpites spp. cenozone}

\section{Lithology}

The lowermost lignite and intervening shale unit. Thickness is about $8 \mathrm{~m}$.

\section{Position}

From sample no. KM-12/19 to KM-12/23. 


\section{Important taxa}

In relation to the overlying assemblage, the litho-unit of this cenozone is poor in pollen yield. All the samples were studied but the pollen diagram shows the presence of palynomorphs only at sample number KM-12/23, as the yield was not enough for quantitative analysis from other samples. In the samples at other depths, Spinizonocolpites echinatus and Polysphaeridium subtile mark their appearance, but the low percentage was a constraint for the quantification at these depths. The cenozone is named after the presence of Spinizonocolpites echinatus present throughout the cenozone. The lower part of lignite consists of terrestrial palynomorphs, belonging to Arecaceae. The other essential taxa recovered are Spinizonocolpites bulbospinosus, Proxapertites cursus, Acanthotricolpites kutchensis and Albertipollenites crassireticulatus. The dinocysts which make their appearance in this zone are Achomosphaera sp., Eocladopyxis peniculata, Homotryblium sp., Kenleyia sp., Spiniferites ramosus, Glaphyrocysta exuberans and Polysphaeridium subtile. The dinocyst assemblage is comprised of Cordosphaeridium exilimurum, Eocladopyxis peniculata, Glaphyrocysta exuberans, Homotryblium sp., Hystrichostrogylon membraniphorum, Polysphaeridium subtile, Spiniferites ramosus and Thalassiphora pelagica. The assemblage of dinocysts is dominated by the genera Polysphaeridium subtile, Glaphyrocysta exuberans and Cordosphaeridium exilimurum. They are observed throughout the section.

Lower limit

The lower limit is not traceable.

\section{Upper limit}

The upper contact is the overlying green shale bed.

\section{Homotryblium floripes cenozone}

\section{Lithology}

Green shales just above the second lignite seam. Thickness is about $3 \mathrm{~m}$.

\section{Position}

From sample no. KM-12/17 to KM-12/7.

\section{Important taxa}

The cenozone is characterized by the absolute dominance of dinocysts with the presence of Albertipollenites crassireticulatus only at one level. The cenozone is named after the first occurrence of the Homotryblium floripes dinocyst, which is an age marker taxon. The important taxa from the shale beds are Achomosphaera spp., Cordosphaeridium cantharellum, C. exilimurum, Glaphyrocysta exuberans, Homotryblium floripes, Hystricholpoma cinctum, Pentadinium sp., Kenleyia spp., Operculodinium divergence, Polysphaeridium subtile, Spiniferites ramosus and Thalassiphora pelagica. A reduction in Polysphaeridium subtile and Thalassiphora pelagica species is observed from the bottom to the top of the section. The assemblage is dominated by Spiniferites sp. and Operculodinium spp.

\section{Lower limit}

The second lignite seam.

\section{Upper limit}

The upper contact is the overlying calcareous mudstone.

Glaphyrocysta exuberans cenozone

\section{Lithology}

Calcareous mudstone. Thickness is about $4 \mathrm{~m}$.

Position

From sample no. KM-12/11 to KM-12/16.

\section{Important taxa}

This cenozone lies above the green shale layer. Here, mangrove pollen, Spinizonocolpites echinatus and Albertipollenites crassireticulatus mark its presence. The dinocysts which were present in Homotryblium floripes cenozone also extended to this zone but their percentage decreases. A drastic reduction in the percentage of Polysphaeridium subtile, Spiniferites ramosus and Operculodinium centrocarpum is observed. Wilsonidium tabulatum, in comparison, appears for the first time in this cenozone.

\section{Lower limit}

The unfossiliferous zone just above the green shales.

\section{Upper limit}

The upper contact is not discernible.

\subsubsection{Panandhro mine}

We have analyzed a total of 16 samples; however, only few yielded good results. The overall assemblage consists of angiosperms, pteridophytes, dinocysts and fungal remains. Only one or two specimens of dinoflagellate Polysphaeridium subtile were discovered from the basal lignitic seam.

The profile has been divided into three cenozones for the convenience of study (Fig. 6). The cenozones are as follows: 
Spinizonocolpites echinatus cenozone

\section{Lithology}

Lower lignite is having a thickness of about $8 \mathrm{~m}$.

Position

From sample no. KP-12/1 to KP-12/8.

\section{Important taxa}

This cenozone is poorly fossiliferous. The cenozone is named after the occurrence and abundance of Spinizonocolpites echinatus, which marks its presence at all levels within the cenozone. The pollen spectra are constructed only for sample number KP-12/5 due to the low percentage of pollen grains at other depths. Spinizonocolpites echinatus, Acanthotricolpites kutchensis and fungal remains were the only palynomorphs constituting the assemblage.

Lower limit

The basement is not exposed.

Upper limit

The upper contact is Meliapollis ramanujamii cenozone.

Meliapollis ramanujamii cenozone

\section{Lithology}

Lignite and overlying highly carbonaceous shale thickness of about $12 \mathrm{~m}$.

\section{Position}

From sample no. KP-12/10 to KP-12/18.

Important taxa

The angiosperm pollen predominantly present in the assemblage is comprised of Acanthotricolpites, Albertipollenites crassireticulatus, Ctenolophonidites costatus, Dipterocarpuspollenites retipilatus, Incrotonipollis neyveli, Meliapollis ramanujamii, Paleosantalaceaepites distinctus, Proxapertites, Spinizonocolpites echinatus, Spinizonocolpites bulbospinosus, Spinomonosulcites, Spinulotetradites juxtatus, Tribrevicolporites sp. Meliapollis ramanujamii and Incrotonipollis neyveli are restricted to this zone only.

Pteridophytes and fungal fruiting bodies were also observed in this cenozone.

\section{Lower limit}

This zone lies above the thin band of dark grey carbonaceous shale.
Upper limit

The upper contact is the overlying carbonaceous shale bed with sand lenses.

Kenleyia spp. cenozone

\section{Lithology}

Carbonaceous shales and calcareous green shale, about $15 \mathrm{~m}$ thickness.

\section{Position}

From sample no. KP-12/20 to KP-12/31.

\section{Important taxa}

The cenozone is characterized by the presence of both terrestrial and marine palynomorphs. The assemblage is comprised of the taxa Thalassiphora fenestrata, T. patula, Kenleyia sp., Glaphyrocysta exuberans, Homotryblium floripes and Polysphaeridium subtile. The cenozone is named after the dominance of dinocysts ascribed to Kenleyia genera. The angiosperms are the second most dominant group in the assemblage characterized by the pollen grains of Albertipollenites crassireticulatus, Ctenolophonidites costatus, Dipterocarpuspollenites retipilatus, Proxapertites cursus, Spinizonocolpites echinatus, S.bulbospinosus and Spinomonosulcites echinatus. The other essential palynomorphs are Arengapollenites achinatus, Longapertites sp., Palmaepollenites ovatus, Lakiapollis ovatus, Retipollenites echinulatus, Incrotonipollis neyveli, Spinulotetradites juxtatus and Margocolporites venkatachalae, Tribrevicolporites eocenicus and Tricolpites sp.

\section{Lower limit}

The carbonaceous shale with sand lenses. Dinocysts were found from this level.

Upper limit

The upper contact is not discernible.

\subsection{Foraminiferal analysis}

The lignite mine sections of the Giral and Surkha are devoid of foraminifera. However, the Matanomadh and Panandhro mine sections are comprised of remarkably well-preserved foraminifera. The characteristics of foraminifera from these marginal marine settings are described below.

\subsubsection{Bloom of triserial planktic}

A bloom of planktic foraminifera Jenkinsina columbiana ( $>30 \%$ ) is found (40\% of abundance observed at $\sim 4.5 \mathrm{~m}$ 
and $\sim 15 \%$ of abundance at $\sim 18 \mathrm{~m}$ depth) in the Panandhro lignite mine (Fig. 11a). The triserial planktic foraminifera are usually observed in the top portion of the seawater along the continental margins, and its percentage increases near the shelf edge, indicating eutrophic conditions (Kroon and Nederbragt, 1990).

\subsubsection{Low-diversity assemblages}

The diversity of foraminifera (planktic plus benthic) remains low in the Matanomadh (Fig. 11b; Fisher alpha: $\alpha \approx 1.5$ to 7 and Shannon-Weaver indices: $H \approx 1.3$ to 2.4 ) and Panandhro mine sections. However, towards the top of the Panandhro section, there is a drastic increase in the diversity (Fig. 11a: from $\alpha \approx 6$ to $47 ; H \approx 1.5$ to 3.6 ) and abundance of foraminifera.

\subsubsection{High abundance of rectilinear benthic foraminifera}

The RBF percentage in the Matanomadh mine section is quite high throughout $(>40 \%)$. Brizalina sp. $(\sim 5 \%$ to $45 \%)$ and Trifarina advena rajasthanensis $(\sim 20 \%-45 \%)$ species belonging to the RBF morphogroup are abundant in the Matanomadh section (Fig. 11b). In the Panandhro section, the RBF percentage varies between $\sim 5 \%$ and $20 \%$. Brizalina sp. $(\sim 5 \%$ to $10 \%)$ belonging to RBF morphogroups are common in the Panandhro section (Fig. 11a).

\section{Discussion}

The Indian subcontinent began its northward journey after its separation from the Gondwanaland around the Cretaceous (P. Kumar et al., 2007). The subcontinent carried flora and fauna from Africa to Asia. The Deccan volcanism covered the western and central portions of the subcontinent with basaltic lava flows, rendering it inhospitable for the growth of flora and fauna on the mainland. Following this, during the Late Paleocene, extensive weathering occurred, which gave rise to the soil cover in the subcontinent. The phase of sediment deposition occurred around the Early Eocene, coinciding with the marine transgression along the Kutch, Cambay and Rajasthan basins. Major parts of the mainland were covered with marine sediments ranging from glauconitic shales to limestones; however, some restricted marine areas along the coast gave rise to lignite deposits comprised dominantly of angiosperms (Sarkar et al., 2012; Saraswati et al., 2012).

\subsection{Paleoenvironment in the Early Eocene in western India}

In the Early Eocene, India was positioned at the Equator (Ocean Drilling Stratigraphic Network, 2004), and the tropical climate enhanced the production of mangrove forests along the western coast of India (Fig. 1a). The modern ana$\log$ of these are the Sunderbans mangrove forests, along the Ganges-Brahmaputra Delta on the eastern coast of India. The Early Eocene sections of the Surkha and Giral mines consist of palynofloral assemblage belonging to the Arecaceae, Cyatheaceae, Lycopodiaceae, Matoniaceae, Osmundaceae, Schizaeaceae, Ctenolophonaceae, Sapotaceae, Alangiaceae and Bombacaceae families which relate to subtropical-tropical climate in their present-day distribution (Sect. S3 in the Supplement).

The lignite seams from both the Giral and Surkha mines are dominant in tropical rainforest elements (Retipollenites, Arengapollenites, Longapertites), which declines gradually towards the top of the section (Figs. 3 and 4). The basal zone consisting of the tropical rainforest gets steadily replaced by an ecosystem in which mangroves form the majority (mangroves $\sim 55 \%-100 \%$ in all samples in the Giral mine; Fig. 7; $\sim 20 \%-80 \%$ in most samples of the Surkha mine; Fig. 8). The abundance of mangrove elements (Nypa), along with the appearance of dinoflagellates, increases in the shales deposited above the lignite seam (in the Surkha mine, dinoflagellate abundance reaches $45 \%$; Fig. 8; in the Giral mine, it reaches $25 \%$ above the lignite; Fig. 7). Different species of mangrove elements (Nypa) like Proxapertites, Palmaepollenites, Spinizonocolpites and Acanthotricolpites were observed towards the top of the Giral and Surkha mine sections, which indicate the proximity of the site of deposition to the coastal area. The size of Nypa pollen is quite large and hence cannot be transported to more considerable distances, and thus its abundance indicates that the source and depositional site were not entirely far off (Chaloner, 1968). Lakiapollis ovatus, which is observed in the basal part $(\sim 8 \mathrm{~m}$ depth; Fig. 4) of the Surkha mine section, exhibits affinity with the modern plant Durio, which is currently found in Indo-Malayan tropics. The taxa Lakiapollis ovatus (Todisporites major, T. minor), Laevigatosporites cognatus, Polypodiisporites repandus and Lycopodiumsporites are found in the lowermost part of the Surkha mine section constituting tropical rainforest vegetation and were gradually replaced by mangroves (Figs. 4 and 8) towards the top. A warm, humid climatic condition with high precipitation is indicated by the presence of microthyriaceous fungal fruiting bodies (Dilcher, 1965; Selkirk, 1975) in the Apectodinium homomorphum cenozone of the Giral mine section (Fig. 3). The dominance of mangroves towards the top of the section in both the Giral and Surkha mines is indicative of the increase of coastal water influence on the mainland (Figs. 3 and 4). The dinoflagellates which are commonly found in the Cambay and Giral mine sections consist of Kenleyia sp., Cordosphaeridium sp. and Apectodinium homomorphum, respectively. The first occurrence of Apectodinium homomorphum is observed in the middle part of the Giral mine ( $7 \mathrm{~m}$ depth; Fig. 3 ), which indicates deposition at high temperatures (Frieling and Sluijs, 2018), especially during the PETM. In the Surkha section, the thermophilic dinoflagellates Cordosphaeridium sp. and Achomosphaera sp. are found, which also indicates deposition at high temperatures. 


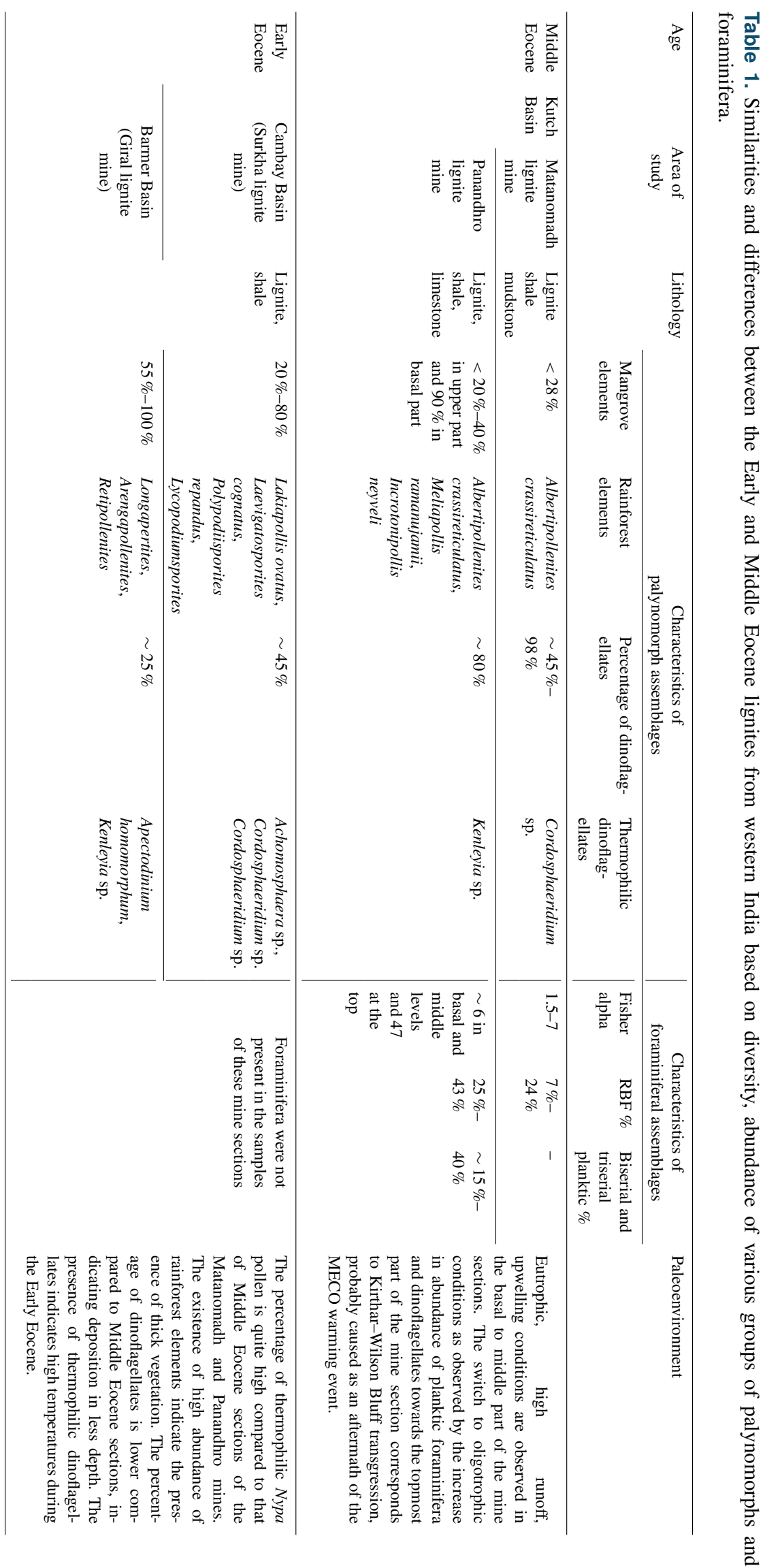




\subsection{Paleoenvironment during the Middle Eocene in western India}

The Indian continent was placed within the tropical belt during the Middle Eocene (Fig. 1b). The basal part consisting of lignites in both mine sections of the Kutch Basin exhibits a dominance of Albertipollenites and Meliapollis ramanujamii, and Dipterocarpuspollenites and Incrotonipollis belonging to family Euphorbiaceae. The dominance of $\mathrm{Eu}$ phorbiaceae is indicative of the prevalence of rainforests in subtropical to tropical climate (Langenheim, 1995; Dutta et al., 2011). Even though the vegetation was predominantly angiosperm rich, the percentage of mangrove forests (particularly the Nypa pollen) decreased and the percentage of dinoflagellates increased (Figs. 9 and 10) in the Middle Eocene compared to the Early Eocene in western India. The pteridophyte percentage is also considerably low in the Middle Eocene $(\sim 25 \%)$, as observed in both mine sections. The percentage of mangrove elements is very low $(<28 \%)$ in the Matanomadh mine section; however, in the Panandhro section, there is a drastic decrease in percentage of mangrove elements from $\sim 90 \%$ in the basal part to $\sim 20 \%$ $40 \%$ in the upper levels. On the contrary, the dinocysts became quite abundant $(\sim 45 \%-98 \%$ in most samples in the Matanomadh section and $\sim 80 \%$ at few levels in the Panandhro section) as compared to Early Eocene sections in the Cambay and Barmer basins. The abundance of dinoflagellate Spiniferites increased towards the top in both mine sections $(\sim 5 \%$ at $9.8 \mathrm{~m}$ to $\sim 25 \%-60 \%$ between 2 and $6.5 \mathrm{~m}$ in the Matanomadh section; refer to Fig. 5; first appearance at $\sim 21 \mathrm{~m}$ in the top part of the Panandhro section; refer to Fig. 6), indicating deposition in low-nutrient, low-TOC (total organic content) and open marine conditions (inner neritic to outer neritic) (Frieling and Sluijs, 2018; Brinkhuis, 1994) towards the upper portion of the mine sections. Species of Operculodinium are generally abundant in restricted marine conditions, as observed by Brinkhuis (1994), from the Late Eocene-Oligocene section of northeast Italy. The abundance of Operculodinium decreases from the bottom to the top within the shale unit deposited above the lignite seam in the Matanomadh mine (decrease in percentage from $\sim 40 \%$ at $6.8 \mathrm{~m}$ within the Homotryblium floripes cenozone to $10 \%$ at $2.8 \mathrm{~m}$ within the Glaphyrocysta exuberans cenozone; refer to Fig. 5), indicating a change from restricted marine to an open marine environment. A high abundance of Thalassiphora pelagica is observed in the carbonaceous shale deposited between two lignite seams $(\sim 20 \%$ at $9.8 \mathrm{~m}$; refer to Fig. 5) from the Matanomadh mine section, representing an increase in productivity of surface waters as well as anaerobic bottom water conditions (Pross, 2001). Similar conditions are observed in the Late Eocene hemipelagic-pelagic sediments of central Italy (Pross and Schmiedl, 2002; Sluijs et al., 2005). T. pelagica in not observed in the upper portion of the Matanomadh mine section; however, the abundance of Homotryblium increases towards the top (Fig. 5). Homotry- blium does not have any extant representatives and is dominantly found in low-latitude warm climates, especially in restricted marine settings with increased salinity (Brinkhuis, 1994; Sluijs et al., 2005), while T. pelagica is observed in relatively reduced salinity conditions. The alternation of abundance between Homotryblium (highest percentage of $\sim 40$ at $6.8 \mathrm{~m}$ in the section; Fig. 5) and T. pelagica (highest percentage $\sim 100$ at $9.8 \mathrm{~m}$ in the section; Fig. 5) corresponds to the increase and decrease in salinity conditions, respectively (Sluijs et al., 2005), in the Matanomadh mine section. The presence of Cordosphaeridium in the green shale (percentage $\sim 5$ to 15 between 2.5 to $6.8 \mathrm{~m}$; refer to Fig. 5) in the Matanomadh mine section corresponds to high temperature and open marine conditions (Frieling and Sluijs, 2018) possibly coinciding with MECO warming event in the Bartonian (Khanolkar et al., 2017). A drastic increase in diversity and abundance of both planktic and benthic foraminifera is observed at the top part ( $\sim 4 \mathrm{~m}$ depth; Fig. 11a) of the Panandhro section, which is also observed across all sedimentary basins in western India (Saraswati et al., 2018). The sea level increased on the western margin of India due to the Kirthar transgression event in the E12 zone, probably related to an aftermath of MECO (Saraswati et al., 2018). The expression of this event is the deposition of marine shales above the lignite seams in both the Panandhro and Matanomadh mines (Fig. 11a and b; Sect. S1 in the Supplement). These marine shales consisted of typical Bartonian foraminifera like Acarinina rohri, Acarinina topilensis, Turborotalia frontosa, Nummulites spectabilis, Linderina kutchensis and Halkyardia minima, and the relative percentage and diversity of foraminifera and dinoflagellates increased from the Early to Middle Eocene (Khanolkar et al., 2017; Sharma and Saraswati, 2015). The bloom of triserial planktic foraminifer Jenkinsina columbiana in the glauconitic shale levels (40\% of abundance observed at $\sim 4.5 \mathrm{~m}$ and $\sim 15 \%$ of abundance at $\sim 18 \mathrm{~m}$ depth; Fig. 11a) in the Panandhro mine section is suggestive of dysoxic and upwelling conditions. Concomitantly, a dominance of rectilinear benthic foraminifera like Brizalina, Trifarina advena rajasthanensis, Buliminella pupa and Buliminella pulchra (> $40 \%$ ) from shales in the Matanomadh mine (especially between 3.5 and $5.5 \mathrm{~m}$ depth; Fig. 11b) is observed, which indicates deposition in lowoxygen and upwelling conditions (Khanolkar and Saraswati, 2013). The agglutinated foraminifera like Miliammina, Textularia, Valvulina and Coskinolina appear in shale layers above the lignite seam, indicating deposition in marsh and sheltered conditions (Coskinolina and Valvulina are observed between 6 and $6.5 \mathrm{~m}$ in shale layers in the Matanomadh section (Fig. 11b), while Miliammina and Textularia are observed between depths of 1 and $3 \mathrm{~m}$ in the mudstone layers of the Panandhro section; Fig. 11a) (Murray, 2006). The presence of atypical planktic foraminifera from the Matanomadh section also indicates the stressed condition of deposition in the restricted marine setting, probably caused by the MECO warming event (Fig. 11b) (Khanolkar and Saraswati, 2016). 
A sharp increase in diversity and abundance of foraminifera is observed at the topmost shale layer within the Panandhro lignite mine section, which corresponds to the Kirthar transgression event recorded within the Kutch Basin (Saraswati et al., 2018).

\subsection{Correlation with global events and stratigraphic implications}

The Early Eocene sections from Tasmania, Tanzania, Africa and Egypt have exhibited a tropical mangrove forest domination (Contreras et al., 2014). Similarly, the Early Eocene sections of the Cambay and Barmer basins in India also indicate an overall domination of mangrove vegetation (Arecaceae, Bombacaceae groups; refer to Figs. 3, 4, 7 and 8). The pollen flora belonging to the Arecaceae group have also been discovered in the Arctic-Siberian and Antarctic regions, indicating the prevalence of tropical to subtropical vegetation belts even at higher latitudes in the Early Eocene (Suan et al., 2017; Contreras et al., 2013). The first appearance of the thermophilic Apectodinium in the Early Eocene lignite is observed in the Giral lignite section of the Barmer Basin (Fig. 3). The percentage of Apectodinium in the Giral section remains low ( $~ 5$ to 10 ; Fig. 3 ). A high abundance of Apectodinium is reported from other low-latitude sections of Pakistan, the US Gulf Coast and north Africa throughout the Early Eocene, along with the thermophilic Kenleyia, which follows an autotrophic lifestyle (Harrington, 2001; Crouch et al., 2003). The presence of Apectodinium is common before the PETM from low-latitude sites (Frieling et al., 2018); however, usually, its first appearance and first acme are correlated with the PETM. Recent reports from the high-latitude site of the Otway Basin in Australia, however, suggested that the acme of Apectodinium predates the PETM by $\sim 50-$ $500 \mathrm{kyr}$ in the basin (Frieling and Sluijs, 2018). In the Cambay Basin, Clementz et al. (2011) established the presence of EECO, which may have led to the abundance of thermophilic Nypa and Kenleyia. However, Apectodinium is not yet reported from the Cambay Basin, and its abundance in the Giral section remains low.

A gap in sedimentation exists from the late Early Eocene to late Middle Eocene and is observed across basins in India, Pakistan and Australia, referred to as the Lutetian gap, and is also recorded in the Kutch Basin (McGowran et al., 2004; Saraswati et al., 2018; Fig. 2). The mangroves continued to flourish in the tropics in the Middle Eocene; however, in the high latitudes, the tropical vegetation which prevailed in the Early Eocene was replaced by temperate flora, e.g., the growth of temperate Nothofagus trees on Wilkes Island, Antarctica (Contreras et al., 2013). Nypa mangroves from the Middle Eocene of Texas were dominated by Spinizonocolpites genera like those observed in the Matanomadh and Panandhro lignite sections of the Kutch Basin and thus may have had similar paleodepositional conditions (Rull, 1998; Westgate and Gee, 1990). Further, the earliest record of marine snake Pterosphenus was reported from the Middle Eocene of Texas and its morphologically advanced form, Pterosphenus kutchensis, which thrived in mangrove-dominated brackish waters, was recorded from the Panandhro lignite mine by Rage et al. (2003). The sediments that have been deposited above the Lutetian gap were recorded in the Panandhro and Matanomadh mine sections of the Kutch Basin (P12-P13 zone) during the Bartonian transgression caused by MECO (Khanolkar et al., 2017) and are comprised of lignites, shales and limestones composed dominantly of dinoflagellates and foraminifera. The increase in percentage of dinoflagellates can be observed in the Middle Eocene compared to the Early Eocene sections of western India. The increase in abundance of planktic foraminifera Acarinina is indicative of warm surface waters and is reported from the MECO warming event of Italy and towards the top of the Panandhro section (Luciani et al., 2010; Khanolkar et al., 2017). This sharp increase in the foraminiferal abundance corresponds to the Kirthar transgression which flooded the sedimentary basins of India and Pakistan (Nagappa, 1959) and is isochronous to the Wilson Bluff transgression in Australia (McGowran, 1977, 1979) along the upper part of E11 planktic foraminiferal zone in the Bartonian.

\section{Conclusions}

The Early and Middle Eocene palynomorph assemblages from lignite mines in western India represent an overall tropical vegetation pattern; however, our current study further pointed out the following similarities and differences in terms of paleovegetation and paleodepositional conditions (Table 1). During the Early Eocene, angiosperms like Arengapollenites achinatus, Longapertites retipilatus and Longapertites sp. constituted the rainforest elements and along with mangrove vegetation gave rise to the thick lignite deposits in the marginal marine setting of the Cambay and Barmer basins. An increase in abundance and diversity of Nypa species (Acanthotricolpites robustus, A. bulbospinosus, A. brevispinosus, A. tiruchirapalliensis, Arengapollenites achinatus, Spinizonocolpites baculatus, S. bulbospinosus, S. echinatus, S. adamanteus, S. prominatus, Spinomonosulcites echinatus) characterized the Early Eocene lignites. The percentage and diversity of dinoflagellates was low in both sections, indicating low depth. The first occurrence of the thermophilic dinoflagellates Apectodinium homomorphum and Kenleyia sp. within the carbonaceous shales of the Barmer Basin indicates the prevalence of hot climate across the Early Eocene. In the Cambay Basin, the presence of dinoflagellates Achomosphaera sp. and Cordosphaeridium sp. was recorded within the shales and is also indicative of high temperatures. The lignites of the Early Eocene were deposited in hot and humid marginal marine conditions. The Middle Eocene vegetation was characterized by rainforest elements (Longaper- 
tites retipilatus, Palmaepollenites ovatus, Lakiapollis ovatus, Tribrevicolporites sp., Meliapollis ramanujamii, Dipterocarpuspollenites retipilatus, Paleosantalaceaepites distinctus), along with mangrove elements (Spinizonocolpites echinatus, S. bulbospinosus, Acanthotricolpites kutchensis, Albertipollenites crassireticulatus) which gave rise to significant organic detritus to form the lignite deposits in the Kutch Basin. The abundance and diversity of Nypa had been reduced, while those of dinoflagellates increased significantly compared to Early Eocene lignites. The characteristics of foraminiferal assemblage recorded from the Kutch mine sections including bloom in triserial planktics and RBFs, low diversity and the presence of atypical planktic foraminifera are indicative of eutrophic and stressed conditions of deposition. However, there was a drastic increment in percentage and diversity of foraminifera observed at the uppermost portion of the Panandhro mine section which exhibited a change in trophic regime from eutrophic to oligotrophic and deposition in open marine conditions. This rise in sea level, which can be correlated with the Kirthar-Wilson Bluff transgression, may have been linked with the MECO hyperthermal event in the Bartonian.

Data availability. The data is provided in Sect. 2 of the Supplement; the micropaleontological slides comprising the foraminifera are in the microscopy lab, Department of Earth Sciences, Indian Institute of Technology Kanpur; the palynomorph slides are housed in the Department of Geology, K. J. Somaiya College of Science and Commerce, University of Mumbai.

Supplement. The supplement related to this article is available online at: https://doi.org/10.5194/jm-38-1-2019-supplement.

Author contributions. SK wrote the manuscript and carried out foraminiferal analysis. JS carried out palynomorph analysis.

Competing interests. The authors declare that they have no conflict of interest.

Acknowledgements. Sonal Khanolkar and Jyoti Sharma thank the Department of Science and Technology, India (project nos. DST/INSPIRE/04/2016/002525 and DST-WOSA PSR/WOS A/ES_31/2011) for providing the funding for carrying out this research work. Jyoti Sharma and Sonal Khanolkar are grateful to the Indian Institute of Technology Bombay and Indian Institute of Technology Kanpur for providing the facilities to carry out this work. We are thankful to the two anonymous reviewers and the handling editor Francesca Sangiorgi for the constructive comments which helped us improve the manuscript. We would like to dedicate this paper to Pratul Kumar Saraswati, IIT Bombay, who has been a motivation for our work and has played an important role in revising the Paleogene biostratigraphy of western India.
Sonal Khanolkar would like to thank Manudeo Singh for help with the preparation of figures.

Edited by: Francesca Sangiorgi

Reviewed by: two anonymous referees

\section{References}

Alegret, L., Ortiz, S., Arenillas, I., and Molina, E.: What happens when the ocean is overheated? The foraminiferal response across the Paleocene-Eocene Thermal Maximum at the Alamedilla section (Spain), Bull. Geol. Soc. Am., 122, 16161624, https://doi.org/10.1130/B30055.1, 2010.

Arenillas, I., Molina, E., and Schmitz, B.: Planktic foraminiferal and ${ }^{13} \mathrm{C}$ isotopic changes across the Paleocene/Eocene boundary at Possagno (Italy), Int. J. Earth Sci., 88, 352-364, 1999.

Bajpai, S., Kapur, V., Das, D., Tiwari, B., Saravanan, N., and Sharma, R.: Early Eocene land mammals from Vastan lignite mine, district Surat (Gujarat), western India, J. Palaeontol. Soc. Ind., 50, 101-113, 2005.

Biswas, S.: Tertiary stratigraphy of Kutch, J. Palaeontol. Soc. Ind., 37, 1-29, 1992.

Brinkhuis, H.: Late Eocene to Early Oligocene dinoflagellate cysts from the Priabonian type-area (Northeast Italy): biostratigraphy and paleoenvironmental interpretation, Palaeogeogr. Palaeocl., 107, 121-163, 1994.

Chaloner, W.: The palaeoecology of fossil spores, Evolution and environment, Yale University Press, New Haven, Connecticut, USA, 125-138, 1968.

Chandra, P. and Chowdhary, L.: Stratigraphy of the Cambay basin, Bull. ONGC, 6, 37-50, 1969.

Clay Kelly, D., Bralower, T. J., Zachos, J. C., Silva, I. P., and Thomas, E.: Rapid diversification of planktonic foraminifera in the tropical Pacific (ODP Site 865) during the late Paleocene thermal maximum, Geology, 24, 423-426, 1996.

Clementz, M., Bajpai, S., Ravikant, V., Thewissen, J., Saravanan, N., Singh, I., and Prasad, V.: Early Eocene warming events and the timing of terrestrial faunal exchange between India and Asia, Geology, 39, 15-18, 2011.

Contreras, L., Pross, J., Bijl, P. K., Koutsodendris, A., Raine, J. I., van de Schootbrugge, B., and Brinkhuis, H.: Early to middle Eocene vegetation dynamics at the Wilkes Land Margin (Antarctica), Rev. Palaeobot. Palyno., 197, 119-142, 2013.

Contreras, L., Pross, J., Bijl, P. K., O’Hara, R. B., Raine, J. I., Sluijs, A., and Brinkhuis, H.: Southern high-latitude terrestrial climate change during the Palaeocene-Eocene derived from a marine pollen record (ODP Site 1172, East Tasman Plateau), Clim. Past, 10, 1401-1420, https://doi.org/10.5194/cp-10-1401-2014, 2014.

Cramwinckel, M. J., Huber, M., Kocken, I. J., Agnini, C., Bijl, P. K., Bohaty, S. M., Frieling, J., Goldner, A., Hilgen, F. J., Kip, E. L., Peterse, F., van der Ploeg, R., Röhl, U., Schouten, S., and Sluijs, A.: Synchronous tropical and polar temperature evolution in the Eocene, Nature, 559, 382-386, https://doi.org/10.1038/s41586018-0272-2, 2018.

Crouch, E. M., Dickens, G. R., Brinkhuis, H., Aubry, M. P., Hollis, C. J., Rogers, K. M., and Visscher, H.: The Apectodinium acme and terrestrial discharge during the Paleocene-Eocene thermal maximum: New palynological, geochemical and calcareous 
nannoplankton observations at Tawanui, New Zealand, Palaeogeogr. Palaeocl., 194, 387-403, https://doi.org/10.1016/S00310182(03)00334-1, 2003.

Dilcher, D. L.: Epiphyllous fungi from Eocene deposits in western Tennessee, USA, Palaeontogr. Abt. B, 116, 1-54, 1965.

Dolson, J., Burley, S. D., Sunder, V., Kothari, V., Naidu, B., Whiteley, N. P., Farrimond, P., Taylor, A., Direen, N., and Ananthakrishnan, B.: The discovery of the Barmer Basin, Rajasthan, India, and its petroleum geology Barmer Basin Petroleum Geology, India, AAPG Bull., 99, 433-465, 2015.

Dutta, S., Tripathi, S. M., Mallick, M., Mathews, R. P., Greenwood, P. F., Rao, M. R., and Summons, R. E.: Eocene out-of-India dispersal of Asian dipterocarps, Rev. Palaeobot. Palyno., 166, 6368, 2011.

Evans, D., Sagoo, N., Renema, W., Cotton, L. J., Müller, W., Todd, J. A., Saraswati, P. K., Stassen, P., Ziegler, M., and Pearson, P. N.: Eocene greenhouse climate revealed by coupled clumped isotope $\mathrm{Mg} / \mathrm{Ca}$ thermometry, P. Natl. Acad. Sci. USA, 115, 1174-1179, 2018.

Frieling, J. and Sluijs, A.: Towards quantitative environmental reconstructions from ancient nonanalogue microfossil assemblages: Ecological preferences of Paleocene-Eocene dinoflagellates, Earth-Sci. Rev., 185, 956-973, 2018.

Frieling, J., Reichart, G.-J., Middelburg, J. J., Röhl, U., Westerhold, T., Bohaty, S. M., and Sluijs, A.: Tropical Atlantic climate and ecosystem regime shifts during the Paleocene-Eocene Thermal Maximum, Clim. Past, 14, 39-55, https://doi.org/10.5194/cp-1439-2018, 2018.

Garg, R., Ateequzzaman, K., Prasad, V., Tripathi, S., Singh, I., Jauhri, A., and Bajpai, S.: Agediagnostic dinoflagellate cysts from the lignite-bearing sediments of the Vastan lignite mine, Surat District, Gujarat, western India, J. Palaeontol. Soc. India, 53, 99-105, 2008.

Giusberti, L., Coccioni, R., Sprovieri, M., and Tateo, F.: Perturbation at the sea floor during the Paleocene-Eocene Thermal Maximum: Evidence from benthic foraminifera at Contessa Road, Italy, Mar. Micropaleontol., 70, 102-119, 2009.

Grimm, E.: TGView, Illinois State Museum, Research and Collections Center, 2004.

Harrington, G. J.: Pollen assemblages and Palaeocene-Eocene stratigraphy in the Bighorn and Clarks Fork Basins, edited by: Gingerich, P. D., University of Michigan Papers on Paleontology, Vol. 33, 89-96, 2001.

Jaramillo, C., Rueda, M. J., and Mora, G.: Cenozoic plant diversity in the neotropics, Science, 311, 1893-1896, https://doi.org/10.1126/science.1121380, 2006.

Jaramillo, C., Ochoa, D., Contreras, L., Pagani, M., Carvajal-Ortiz, H., Pratt, L. M., Krishnan, S., Cardona, A., Romero, M., Quiroz, L., Rodriguez, G., Rueda, M. J., De La Parra, F., Morón, S., Green, W., Bayona, G., Montes, C., Quintero, O., Ramirez, R., Mora, G., Schouten, S., Bermudez, H., Navarrete, R., Parra, F., Alvarán, M., Osorno, J., Crowley, J. L., Valencia, V., and Vervoort, J.: Effects of rapid global warming at the paleoceneeocene boundary on neotropical vegetation, Science, 330, 957961, https://doi.org/10.1126/science.1193833, 2010.

Kalia, P.: Buliminds from the Middle Eocene of Rajasthan, India, J. Palaeontol. Soc. India, 21, 44-48, 1978.

Kelly, D. C., Bralower, T. J., and Zachos, J. C.: Evolutionary consequences of the latest Paleocene thermal maximum for tropical planktonic foraminifera, Palaeogeogr. Palaeocl., 141, 139-161, 1998.

Khanolkar, S. and Saraswati, P. K.: Palaeoenvironmental Significance of Rectilinear Benthic Foraminifera in the Middle Eocene section of Matanaomadh Sub-basin, Kutch, Proceedings of XXIII Indian Colloquium of Micropaleontology and Stratigraphy, Special Publication Geological Society of India, 1, 307-317, 2013.

Khanolkar, S. and Saraswati, P. K.: Ecological response of shallowmarine foraminifera to early Eocene warming in equatorial India, J. Foramin. Res., 45, 293-304, 2015.

Khanolkar, S. and Saraswati, P. K.: Some observations on an atypical planktic foraminifer from the Middle Eocene of Kutch, India, J. Micropalaeontol., 35, 54-61, https://doi.org/10.1144/jmpaleo2015-004, 2016.

Khanolkar, S., Kumar Saraswati, P., and Rogers, K.: Ecology of foraminifera during the middle Eocene climatic optimum in Kutch, India, Geodin. Acta, 29, 181-193, 2017.

Kroon, D. and Nederbragt, A. J.: Ecology and paleoecology of triserial planktic foraminifera, Mar. Micropaleontol., 16, 25-38, 1990.

Kumar, K., Rana, R. S., and Singh, H.: Fishes of the Khuiala Formation (Early Eocene) of the Jaisalmer Basin, Western Rajasthan, India, Curr. Sci. India, 93, 553-559, 2007.

Kumar, M.: Palynostratigraphy and palaeoecology of early Eocene palynoflora of Rajpardi lignite, Bharuch District, Gujarat, 1994.

Kumar, P., Yuan, X., Kumar, M. R., Kind, R., Li, X., and Chadha, R.: The rapid drift of the Indian tectonic plate, Nature, 449, 894 897, 2007.

Langenheim, J. H.: Biology of amber-producing trees: Focus on case studies of Hymenaea and Agathis, in: Amber, Resinite and Fossil Resins, edited by: Anderson, K. G. and Crelling, J. C., American Chemical Society Symposium Series 617, Washington, DC, 1-31, 1995.

Loeblich Jr., A. R. and Tappan, H.: Foraminiferal genera and their classification, Springer, New York, 2015.

Luciani, V., Giusberti, L., Agnini, C., Fornaciari, E., Rio, D., Spofforth, D. J., and Pälike, H.: Ecological and evolutionary response of Tethyan planktonic foraminifera to the middle Eocene climatic optimum (MECO) from the Alano section (NE Italy), Palaeogeogr. Palaeocl., 292, 82-95, 2010.

Mandal, J. and Guleria, J. S.: Palynology of Vastan Lignite (Surat District) Gujarat: its age palaeoecology and depositional environment, Palaeobotanist, 55, 51-66, 2006.

McGowran, B.: Maastrichtian to Eocene foraminiferal assemblages in the northern and eastern Indian Ocean region: Correlations and historical patterns, in: Indian Ocean geology and biostratigraphy, edited by: Heirtzler, J. R., Bolli, H. M., Davies, T. A., Saunders, J. B., and Sclater, J. G., American Geophysical Union Special Publication, 417-458, https://doi.org/10.1029/SP009p0417, 1977.

McGowran, B.: The Tertiary of Australia: foraminiferal overview, Mar. Micropaleontol., 4, 235-264, 1979.

McGowran, B., Holdgate, G. R., Li, Q., and Gallagher, S. J.: Cenozoic stratigraphic succession in southeastern Australia, Aust. J. Earth Sci., 51, 459-496, 2004.

Murray, J. W.: Ecology and applications of benthic foraminifera, Cambridge University Press, 2006. 
Murray, J. W. and Wright, C. A.: Palaeogene foraminiferida and palaeoecology, Hampshire and Paris Basins and the English Channel, 14, Palaeontological Association, 14, 1-129, 1974.

Naafs, B. D. A., Rohrssen, M., Inglis, G. N., Lähteenoja, O., Feakins, S. J., Collinson, M. E., Kennedy, E. M., Singh, P. K., Singh, M. P., Lunt, D. J., and Pancost, R. D.: High temperatures in the terrestrial midlatitudes during the early Palaeogene, Nat. Geosci., 11, 766-771, https://doi.org/10.1038/s41561-018-0199$0,2018$.

Nagappa, Y.: Foraminiferal biostratigraphy of the CretaceousEocene succession in the IndiaPakistan-Burma region, Micropaleontology, 5, 145-177, 1959.

Nagy, J.: Environmental significance of foraminiferal morphogroups in Jurassic North Sea deltas, Palaeogeogr. Palaeocl., 95, 111-134, 1992.

Nigam, R., Mazumder, A., Henriques, P. J., and Saraswat, R.: Benthic foraminifera as proxy for oxygen-depleted conditions off the central west coast of India, Journal of Geological Society of India, 70, 1047-1051, 2007.

Ocean Drilling Stratigraphic Network: ODSN Plate Tectonic Reconstruction Service, available at: http://www.odsn.de/odsn/ services/paleomap/paleomap.html, last access: April 2004.

Pearson, P. N., Ditchfield, P. W., Singano, J., Harcourt-Brown, K. G., Nicholas, C. J., Olsson, R. K., Shackleton, N. J., and Hall, M. A.: Warm tropical sea surface temperatures in the Late Cretaceous and Eocene epochs, Nature, 413, 481-487, 2001.

Pearson, P. N., Olsson, R. K., Huber, B. T., Hemleben, C., Berggren, W. A., Premoli Silva, I., Coxall, H., Premec Fucek, V., and Wade, B.: Atlas of Eocene planktonic foraminifera, Epitome, 1, 274274, 2005.

Prasad, V., Singh, I. B., Bajpai, S., Garg, R., Thakur, B., Singh, A., Saravanan, N., and Kapur, V. V.: Palynofacies and sedimentology-based high-resolution sequence stratigraphy of the lignitebearing muddy coastal deposits (early Eocene) in the Vastan Lignite Mine, Gulf of Cambay, India, Facies, 59, 737761, 2013.

Preece, R., Kaminski, M., and Dignes, T.: Miocene benthonic foraminiferal morphogroups in an oxygen minimum zone, offshore Cabinda, Geol. Soc. Spec. Publ., 153, 267-282, 1999.

Pross, J.: Paleo-oxygenation in tertiary epeiric seas: Evidence from dinoflagellate cysts, Palaeogeogr. Palaeocl., 166, 369-381, https://doi.org/10.1016/S0031-0182(00)00219-4, 2001.

Pross, J. and Schmiedl, G.: Early Oligocene dinoflagellate cysts from the Upper Rhine Graben (SW Germany): paleoenvironmental and paleoclimatic implications, Mar. Micropaleontol., 45, 124, 2002.

Punekar, J. and Saraswati, P. K.: Age of the Vastan Lignite in context of some oldest Cenozoic fossil mammals from India, J. Geol. Soc. India, 76, 63-68, 2010.

Rage, J.-C., Bajpai, S., Thewissen, J. G., and Tiwari, B. N.: Early Eocene snakes from Kutch, Western India, with a review of the Palaeophiidae, Geodiversitas, 25, 695-716, 2003.

Rana, R., Kumar, K., Singh, H., and Rose, K.: Lower vertebrates from the late palaeocene-earliest eocene Akli formation, giral lignite mine, Barmer District, western India, Curr. Sci. India, 89, 1606-1613, 2005.

Rao, M., Sahni, A., Rana, R., and Verma, P.: Palynostratigraphy and depositional environment of Vastan lignite mine (Early Eocene), Gujarat, western India, J. Earth Syst. Sci., 122, 289-307, 2013.
Reolid, M., Rodríguez-Tovar, F. J., Nagy, J., and Olóriz, F.: Benthic foraminiferal morphogroups of mid to outer shelf environments of the Late Jurassic (Prebetic Zone, southern Spain): characterization of biofacies and environmental significance, Palaeogeogr. Palaeocl., 261, 280-299, 2008.

Rull, V.: Middle Eocene mangroves and vegetation changes in the Maracaibo Basin, Venezuela, Palaios, 13, 287-296, 1998.

Samant, B. and Phadtare, N.: Stratigraphic palynoflora of the Early Eocene Rajpardi lignite, Gujarat andthe lower age limit of the Tarkeswar Formation of South Cambay Basin, India, Palaeontogr. Abt. B, 245, 1-108, 1997.

Samanta, A., Bera, M., Ghosh, R., Bera, S., Filley, T., Pande, K., Rathore, S., Rai, J., and Sarkar, A.: Do the large carbon isotopic excursions in terrestrial organic matter across Paleocene-Eocene boundary in India indicate intensification of tropical precipitation?, Palaeogeogr. Palaeocl., 387, 91-103, 2013.

Saraswati, P. K., Sarkar, U., and Banerjee, S.: Nummulites solitarius - Nummulites burdigalensis lineage in Kutch with remarks on the age of Naredi Formation, J. Geol. Soc. India, 79, 476-482, 2012.

Saraswati, P. K., Khanolkar, S., Raju, D. S. N., Dutta, S., Banerjee, S., Wang, Y., and Liu, M.: Foraminiferal biostratigraphy of lignite mines of Kutch India: Age of lignite fossil vertebrates, J. Palaeogeogr., 3, 90-98, 2014.

Saraswati, P. K., Khanolkar, S., and Banerjee, S.: Paleogene stratigraphy of Kutch, India: an update about progress in foraminiferal biostratigraphy, Geodin. Acta, 30, 100-118, 2018.

Sarkar, U., Banerjee, S., Saraswati, P., Yuan, W., and Min, L.: Integrated borehole and outcrop study for documentation of sea level cycles within the Early Eocene Naredi Formation, western Kutch, India, J. Palaeogeogr., 1, 126-137, 2012.

Selkirk, D.: Tertiary fossil fungi from Kiandra, New South Wales, Proc. Linnean. Soc. NSW, 1975,

Sharma, J. and Saraswati, P. K.: Lignites of Kutch, western India: Dinoflagellate biostratigraphy and palaeoclimate, Revue de Micropaléontologie, 58, 107-119, 2015.

Singh, A., Rai, A., Verma, K., Das, S., and Bharti, S.: Benthic foraminiferal diversity response to the climate induced changes in the eastern Arabian Sea oxygen minimum zone during the last 30 ka BP, Quaternary Int., 374, 118-125, 2015.

Singh, S. and Kalia, P.: A new planktonic foraminifer from the middle Eocene of India, Micropaleontology, 16, 76-82, 1970.

Sluijs, A., Brinkhuis, H., Crouch, E. M., John, C. M., Handley, L., Munsterman, D., Bohaty, S. M., Zachos, J. C., Reichart, G. J., Schouten, S., Pancost, R. D., Damsté, J. S. S., Welters, N. L. D., Lotter, A. F., and Dickens, G. R.: Eustatic variations during the Paleocene-Eocene greenhouse world, Paleoceanography, 23, 118, https://doi.org/10.1029/2008PA001615, 2008.

Sluijs, A., Pross, J., and Brinkhuis, H.: From greenhouse to icehouse; organic-walled dinoflagellate cysts as paleoenvironmental indicators in the Paleogene, Earth-Sci. Rev., 68, 281-315, 2005.

Stassen, P., Steurbaut, E., Morsi, A.-M., Schulte, P., and Speijer, R.: Biotic impact of Eocene Thermal Maximum 2 in a shelf setting (Dababiya, Egypt), Austrian J. Earth Sci., 105, 154-160, 2012.

Suan, G., Popescu, S.-M., Suc, J.-P., Schnyder, J., Fauquette, S., Baudin, F., Yoon, D., Piepjohn, K., Sobolev, N. N., and Labrousse, L.: Subtropical climate conditions and mangrove growth in Arctic Siberia during the early Eocene, Geology, 45, 539-542, 2017. 
Thomas, E. and Shackleton, N. J.: The Paleocene-Eocene benthic foraminiferal extinction and stable isotope anomalies, Geol. Soc. Spec. Publ., 101, 401-441, 1996.

Tripathi, S. K. and Srivastava, D.: Palynology and palynofacies of the early Palaeogene lignite bearing succession of Vastan, Cambay Basin, western India, Acta Palaeobotanica, 52, 157-175, 2012.

Westgate, J. W. and Gee, C. T.: Paleoecology of a middle Eocene mangrove biota (vertebrates, plants, and invertebrates) from southwest Texas, Palaeogeogr. Palaeocl., 78, 163-177, 1990.
Zachos, J., Pagani, M., Sloan, L., Thomas, E., and Billups, K.: Trends, rhythms, and aberrations in global climate $65 \mathrm{Ma}$ to present, Science, 292, 686-693, 2001.

Zamagni, J., Mutti, M., Ballato, P., and Košir, A.: The PaleoceneEocene thermal maximum (PETM) in shallow-marine successions of the Adriatic carbonate platform (SW Slovenia), Bulletin, 124, 1071-1086, 2012. 